\title{
Finance, Financial Sector
Policies, and Long-Run Growth \\ Finance, Financial Sector
Policies, and Long-Run Growth
}

Asli Demirgüç-Kunt

Ross Levine 음 



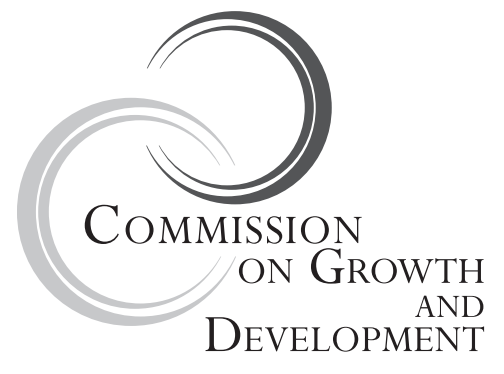

WORKING PAPER NO. 11

\title{
Finance, Financial Sector Policies, and Long-Run Growth
}

\author{
Asli Demirgüç-Kunt \\ Ross Levine
}

Australian Government

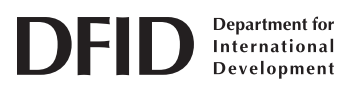

Dutch Ministry

of Foreign Affairs

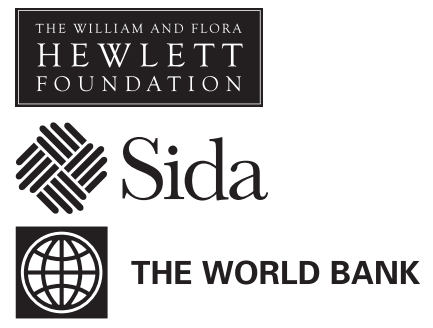


(C) 2008 The International Bank for Reconstruction and Development / The World Bank

On behalf of the Commission on Growth and Development

1818 H Street NW

Washington, DC 20433

Telephone: 202-473-1000

Internet: www.worldbank.org

www.growthcommission.org

E-mail: info@worldbank.org

contactinfo@growthcommission.org

All rights reserved

1234511100908

This working paper is a product of the Commission on Growth and Development, which is sponsored by the following organizations:

Australian Agency for International Development (AusAID)

Dutch Ministry of Foreign Affairs

Swedish International Development Cooperation Agency (SIDA)

U.K. Department of International Development (DFID)

The William and Flora Hewlett Foundation

The World Bank Group

The findings, interpretations, and conclusions expressed herein do not necessarily reflect the views of the sponsoring organizations or the governments they represent.

The sponsoring organizations do not guarantee the accuracy of the data included in this work. The boundaries, colors, denominations, and other information shown on any map in this work do not imply any judgment on the part of the sponsoring organizations concerning the legal status of any territory or the endorsement or acceptance of such boundaries.

All queries on rights and licenses, including subsidiary rights, should be addressed to the Office of the Publisher, The World Bank, 1818 H Street NW, Washington, DC 20433, USA; fax: 202-522-2422; e-mail: pubrights@worldbank.org.

Cover design: Naylor Design 


\section{About the Series}

The Commission on Growth and Development led by Nobel Laureate Mike Spence was established in April 2006 as a response to two insights. First, poverty cannot be reduced in isolation from economic growth - an observation that has been overlooked in the thinking and strategies of many practitioners. Second, there is growing awareness that knowledge about economic growth is much less definitive than commonly thought. Consequently, the Commission's mandate is to "take stock of the state of theoretical and empirical knowledge on economic growth with a view to drawing implications for policy for the current and next generation of policy makers."

To help explore the state of knowledge, the Commission invited leading academics and policy makers from developing and industrialized countries to explore and discuss economic issues it thought relevant for growth and development, including controversial ideas. Thematic papers assessed knowledge in areas such as monetary and fiscal policies, climate change, and equity and growth and highlighted ongoing debates. Additionally, 25 country case studies were commissioned to explore the dynamics of growth and change in the context of specific countries.

Working papers in this series were presented and reviewed at Commission workshops, which were held in 2007-08 in Washington, D.C., New York City, and New Haven, Connecticut. Each paper benefited from comments by workshop participants, including academics, policy makers, development practitioners, representatives of bilateral and multilateral institutions, and Commission members.

The working papers, and all thematic papers and case studies written as contributions to the work of the Commission, were made possible by support from the Australian Agency for International Development (AusAID), the Dutch Ministry of Foreign Affairs, the Swedish International Development Cooperation Agency (SIDA), the U.K. Department of International Development (DFID), the William and Flora Hewlett Foundation, and the World Bank Group.

The working paper series was produced under the general guidance of Mike Spence and Danny Leipziger, Chair and Vice Chair of the Commission, and the Commission's Secretariat, which is based in the Poverty Reduction and Economic Management Network of the World Bank. Papers in this series represent the independent view of the authors. 


\section{Abstract}

In this paper, we review research on (1) the relation between finance and growth and (2) the policy and institutional determinants of financial development. Governments play a central role in shaping the operation of financial systems and the degree to which large segments of the economy have access to financial services. 


\section{Contents}

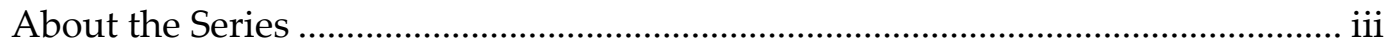

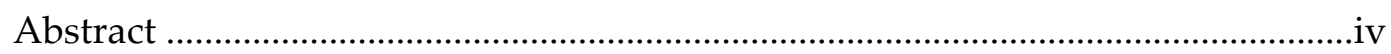

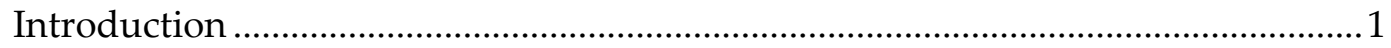

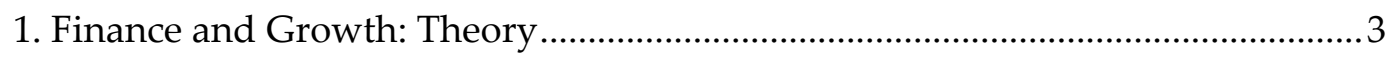

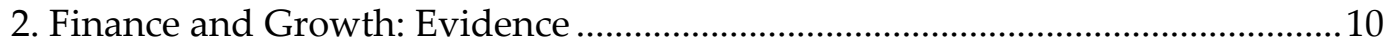

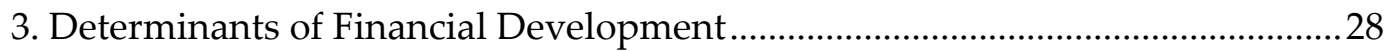

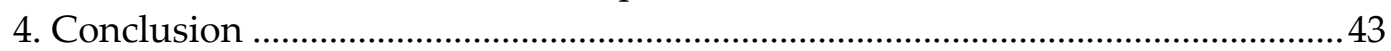

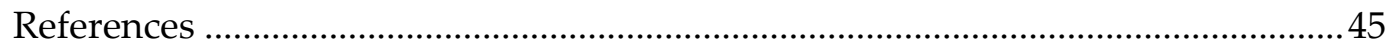





\title{
Finance, Financial Sector Policies, and Long-Run Growth
}

\author{
Asli Demirgüç-Kunt \\ Ross Levine ${ }^{1}$
}

\section{Introduction}

Are financial systems simply casinos where the rich come to place their bets, or do the services provided by the financial system affect the rate of long-run economic growth? Economists disagree about the impact of finance on growth. Many development economists do not even consider finance worth discussing. A collection of essays by the "pioneers of development economics"-including three winners of the Nobel Prize in Economics - does not discuss finance (Meier and Seers, 1984) and leading textbooks on economic growth also ignore the financial sector (Jones, 1998; Weil, 2005). At the other extreme, Nobel Laureate Merton Miller (1998, p. 14) says "that financial markets contribute to economic growth is a proposition almost too obvious for serious discussion." As a third view, Nobel Laureate Robert Lucas (1988) holds that the role of finance in economic growth has been "over-stressed" by the growth literature. Resolving this debate will affect the intensity with which researchers and policy makers attempt to identify and adopt appropriate financial sector policies.

In this paper, we first review the literature on the relation between finance and growth. Theory provides ambiguous predictions concerning the question of whether financial development exerts a positive, causative impact on long-run economic growth. Theoretical models show that financial instruments, markets, and institutions may arise to mitigate the effects of information and transaction costs. In emerging to ameliorate market frictions, financial arrangements change the incentives and constraints facing economic agents. Thus, financial systems may influence saving rates, investment decisions, technological innovation, and hence long-run growth rates. Even putting aside causal issues, a host of theoretical models illustrate the reductions in financial market frictions that increase expected rates of return and improve risk diversification opportunities could increase or decrease growth rates depending on the general equilibrium effects on aggregate saving rates. Furthermore, a comparatively less welldeveloped theoretical literature examines the dynamic interactions between

\footnotetext{
${ }^{1}$ Asli Demirgüç-Kunt is Senior Research Manager of the Finance and Private Sector, Development Research Group, World Bank, Washington, D.C. Ross Levine is James and Merryl Tisch Professor of Economics, and Director of the William R. Rhodes Center for International Economics, Brown University, Providence, RI.
} 
finance and growth by developing models where the financial system influences growth, and growth transforms the operation of the financial system. Thus, financial development might primarily reflect changes in long-run growth opportunities whose mainsprings derive from other sources. Although theory provides a complex array of conflicting conjectures, the empirical evidence is less ambiguous.

A growing body of empirical research produces a remarkably consistent narrative: The services provided by the financial system exert a first-order impact on long-run economic growth. Building on work by Bagehot (1873), Schumpeter (1912), Gurley and Shaw (1955), Goldsmith (1969), and McKinnon (1973), recent research has employed different econometric methodologies and data sets in producing three core results. First, countries with better-developed financial systems tend to grow faster. Specifically, countries with (i) large, privately owned banks that funnel credit to private enterprises and (ii) liquid stock exchanges tend to grow faster than countries with corresponding lower levels of financial development. The level of banking development and stock market liquidity each exerts an independent, positive influence on economic growth. Second, simultaneity bias does not seem to be the cause of this result. Third, better-functioning financial systems ease the external financing constraints that impede firm and industrial expansion. Thus, one channel through which financial development matters for growth is by easing the ability of financially constrained firms to access external capital and expand.

Each examination of the finance-growth nexus has distinct methodological shortcomings, which advertises the value of using different approaches with different strengths and weaknesses in drawing the most accurate inferences possible about the impact of finance on growth. In this paper, we focus on four classes of empirical studies: (i) pure cross-country growth regressions, (ii) panel techniques that exploit both the cross-country and time-series dimensions of the data, (iii) microeconomic-based studies that examine the mechanisms through which finance may influence economic growth, and (iv) individual country cases. They all suggest a strong, positive relationship between the level of financial development and economic growth. One common problem, however, plagues virtually all studies of finance and growth. Theory suggests that financial contracts, markets, and intermediaries arise to reduce information and transaction costs and therefore provide financial services to the economy that facilitate (i) the screening of firms before they are financed; (ii) the monitoring of firms after they are financed; (iii) the managing of risk, both idiosyncratic project risk and liquidity risk; and (iv) the exchange of goods, services, and financial claims. But researchers do not have very good cross-country measures of the ability of the financial system to provide these services to the economy. Designing empirical proxies of "financial development" that correspond more closely to our concepts of financial development represents a valuable area for future research. 
Without ignoring the weaknesses of existing work and the need for future research, the consistency of existing empirical results motivates vigorous inquiry into the policy determinants of financial development as a mechanism for promoting growth in countries around the world. If financial development is crucial for growth, how can countries develop well-functioning financial systems? What legal, regulatory, and policy changes would foster the emergence of growth-enhancing financial markets and intermediaries?

The second part of this paper reviews the literature on the historical and policy determinants of financial development. Governments play a central role in shaping the operation of financial systems and the degree to which large segments of the financial system have access to financial services. We discuss the relationship between financial sector policies and economic development.

The remainder of the paper proceeds as follows. Sections 1 and 2 review theory and evidence on the relation between finance and growth. Section 3 turns to an examination of financial sector policies, and Section 4 concludes.

\section{Finance and Growth: Theory}

\section{What is Financial Development?}

The costs of acquiring information, enforcing contracts, and making transactions create incentives for the emergence of particular types of financial contracts, markets, and intermediaries. Different types and combinations of information, enforcement, and transaction costs in conjunction with different legal, regulatory, and tax systems have motivated distinct financial contracts, markets, and intermediaries across countries and throughout history.

In arising to ameliorate market frictions, financial systems naturally influence the allocation of resources across space and time. For instance, the emergence of banks that improve the acquisition of information about firms and managers will undoubtedly alter the allocation of credit. Similarly, financial contracts that make investors more confident that firms will pay them back will likely influence how people allocate their savings. This section describes models in which market frictions motivate the emergence of financial contracts, markets, and intermediaries that in turn alter incentives in ways that influence economic growth.

We focus on five broad functions provided by the financial system to ease market frictions:

(i) produce information ex ante about possible investments and allocate capital

(ii) monitor investments and exert corporate governance after providing finance

(iii) facilitate the trading, diversification, and management of risk 
(iv) mobilize and pool savings

(v) ease the exchange of goods and services

Although all financial systems provide these financial functions, there are large differences in how well financial systems provide these functions.

Financial development occurs when financial instruments, markets, and intermediaries ameliorate-though do not necessarily eliminate-the effects of information, enforcement, and transactions costs and therefore do a correspondingly better job at providing the five financial functions. Thus, financial development involves improvements in the (i) production of ex ante information about possible investments; (ii) monitoring of investments and implementation of corporate governance; (iii) trading, diversification, and management of risk; (iv) mobilization and pooling of savings; and (v) exchange of goods and services. Since many market frictions exist and since laws, regulations, and policies differ markedly across economies and over time, improvements along any single dimension may have different implications for resource allocation and welfare depending on the other frictions at play in the economy.

\section{Producing Information and Allocating Capital}

There are large costs associated with evaluating firms, managers, and market conditions before making investment decisions. Individual savers may not have the ability to collect, process, and produce information on possible investments. Since savers will be reluctant to invest in activities about which there is little reliable information, high information costs may keep capital from flowing to its highest value use. Thus, although many models assume that capital flows toward the most profitable firms, this presupposes that investors have good information about firms, managers, and market conditions.

Financial intermediaries may reduce the costs of acquiring and processing information and thereby improve resource allocation (Boyd and Prescott, 1986). Without intermediaries, each investor would face the large fixed cost associated with evaluating firms, managers, and economic conditions. Consequently, groups of individuals may form financial intermediaries that undertake the costly process of researching investment possibilities for others.

By improving information on firms, managers, and economic conditions, financial intermediaries can accelerate economic growth. Assuming that many entrepreneurs solicit capital and that capital is scarce, financial intermediaries that produce better information on firms will thereby fund more promising firms and induce a more efficient allocation of capital (Greenwood and Jovanovic, 1990). Besides identifying the best production technologies, financial intermediaries may also boost the rate of technological innovation by identifying those entrepreneurs with the best chances of successfully initiating new goods and production processes (King and Levine, 1993b; Galetovic, 1996; Blackburn and Hung, 1998; and Morales, 2003). 
Stock markets may also stimulate the production of information about firms. As markets become larger and more liquid, agents may have greater incentives to expend resources in researching firms because it is easier to profit from this information by trading in big and liquid markets (Grossman and Stiglitz, 1980; Kyle, 1984; Holmstrom and Tirole, 1993). Intuitively, with larger and more liquid markets, it is easier for an agent who has acquired information to disguise this private information and make money by trading in the market. Thus, larger, more liquid markets will boost incentives to produce this valuable information with positive implications for capital allocation (Merton, 1987).

Finally, capital market imperfections can also influence growth by impeding investment in human capital (Galor and Zeira, 1993). In the presence of indivisibilities in human capital investment and imperfect capital markets, the initial distribution of wealth will influence who can gains the resources to undertake human capital augmenting investments. This implies a suboptimal allocation of resources with potential implications on aggregate output both in the short and the long run.

\section{Monitoring Firms and Exerting Corporate Governance}

Corporate governance is central to understanding economic growth in general and the role of financial factors in particular. The degree to which the providers of capital to a firm can effectively monitor and influence how firms use that capital has ramifications on both savings and allocation decisions. To the extent that shareholders and creditors effectively monitor firms and induce managers to maximize firm value, this will improve the efficiency with which firms allocate resources and make savers more willing to finance production and innovation. In turn, the absence of financial arrangements that enhance corporate governance may impede the mobilization of savings from disparate agents and also keep capital from flowing to profitable investments.

An assortment of market frictions may keep diffuse shareholders from effectively exerting corporate governance, which allows managers to pursue projects that benefit themselves rather than the firm and society at large. In particular, large information asymmetries typically exist between managers and small shareholders and managers have enormous discretion over the flow of information. Furthermore, small shareholders frequently lack the expertise and incentives to monitor managers because of the large costs and complexity associated with overseeing mangers and exerting corporate control. This may induce a "free-rider" problem because each stockowner's stake is so small: Each investor relies on others to undertake the costly process of monitoring managers, so there is too little monitoring. The resultant gap in information between corporate insiders and diffuse shareholders implies that the voting rights mechanism will not work effectively. Also, the board of directors may not represent the interests of minority shareholders. Management frequently "captures" the board and manipulates directors into acting in the best interests of 
the managers, not the shareholders. Finally, in many countries legal codes do not adequately protect the rights of small shareholders and legal systems frequently do not enforce the legal codes that actually are on the books concerning diffuse shareholder rights. Thus, large information and contracting costs may keep diffuse shareholders from effectively exerting corporate governance, with adverse effects on resource allocation and economic growth.

One response to the frictions that prevent dispersed shareholders from effectively governing firms is for firms to have a large, concentrated owner, but this ownership structure has its own problems as reviewed by Laeven and Levine (2008). Large owners have greater incentives to acquire information and monitor managers and greater power to thwart managerial discretion (Grossman and Hart, 1980). The existence of large shareholders, however, creates a different agency problem: Conflicts arise between the controlling shareholder and other shareholders (Jensen and Meckling, 1976). The controlling owner may expropriate resources from the firm, or provide jobs, perquisites, and generous business deals to related parties in a manner that hurts the firm and society, but benefits the controlling owner. Indeed, controlling owners are frequently powerful families that use pyramidal structures, cross-holdings, and super voting rights to magnify their control over many corporations and banks (La Porta et al., 1999; Caprio et al., 2007). To the extent that diffuse or concentrated shareholders do not ameliorate the corporate governance problem, theory suggests that other types of financial arrangements may arise to ease market frictions and improve the governance of corporations.

In terms of intermediaries, a number of models show that well-functioning financial intermediaries influence growth by boosting corporate governance. Bencivenga and Smith (1993) show that financial intermediaries that improve corporate governance by economizing on monitoring costs will reduce credit rationing and thereby boost productivity, capital accumulation, and growth. Sussman (1993) and Harrison, Sussman, and Zeira (1999) develop models where financial intermediaries facilitate the flow of resources from savers to investors in the presence of informational asymmetries with positive growth effects. Focusing on innovative activity, De La Fuente and Marin (1996) develop a model in which intermediaries arise to undertake the particularly costly process of monitoring innovative activities. This improves credit allocation among competing technology producers with positive ramifications on economic growth.

\section{Risk Amelioration}

With information and transactions costs, financial contracts, markets, and intermediaries may arise to ease the trading, hedging, and pooling of risk with implications for resource allocation and growth. We divide the discussion into three categories: cross-sectional risk diversification, intertemporal risk sharing, and liquidity risk. 
Traditional finance theory focuses on cross-sectional diversification of risk. Financial systems may mitigate the risks associated with individual projects, firms, industries, regions, countries, and so forth. Banks, mutual funds, and securities markets all provide vehicles for trading, pooling, and diversifying risk. The financial system's ability to provide risk diversification services can affect long-run economic growth by altering resource allocation and savings rates. The basic intuition is straightforward. Although savers generally do not like risk, high-return projects tend to be riskier than low-return projects. Thus, financial markets that make it easier for people to diversify risk tend to induce a portfolio shift toward projects with higher expected returns (Gurley and Shaw, 1955; Patrick, 1966; Greenwood and Jovanovic, 1990).

In terms of technological change, King and Levine (1993b) show that crosssectional risk diversification can stimulate innovative activity. Agents are continuously trying to make technological advances to gain a profitable market niche. Engaging in innovation is risky, however. The ability to hold a diversified portfolio of innovative projects reduces risk and promotes investment in growthenhancing innovative activities (with sufficiently risk averse agents). Thus, financial systems that ease risk diversification can accelerate technological change and economic growth.

A third type of risk is liquidity risk. Liquidity reflects the cost and speed with which agents can convert financial instruments into purchasing power at agreed prices. Liquidity risk arises due to the uncertainties associated with converting assets into a medium of exchange. Informational asymmetries and transaction costs may inhibit liquidity and intensify liquidity risk. These frictions create incentives for the emergence of financial markets and institutions that augment liquidity.

The standard link between liquidity and economic development arises because some high-return projects require a long-run commitment of capital, but savers do not like to relinquish control of their savings for long-periods. Thus, if the financial system does not augment the liquidity of long-term investments, less investment is likely to occur in the high-return projects. Indeed, Hicks (1969, p. 143-45) argues that the products manufactured during the first decades of the Industrial Revolution had been invented much earlier. Rather, the critical innovation that ignited growth in eighteenth-century England was capital market liquidity. With liquid capital markets, savers can hold liquid assets - like equity, bonds, or demand deposits - that they can quickly and easily sell if they seek access to their savings. Simultaneously, capital markets transform these liquid financial instruments into long-term capital investments. Thus, the industrial revolution required a financial revolution so that large commitments of capital could be made for long periods (Bencivenga, Smith, and Starr, 1995).

Levine (1991) shows that the endogenous formation of equity markets to provide liquidity can affect economic growth. Specifically, savers receiving shocks that increase their need for liquidity can sell their equity claims to the 
future profits of the illiquid production technology to others. Market participants do not verify whether other agents received shocks or not. Participants simply trade in impersonal stock exchanges. Thus, with liquid stock markets, equity holders can readily sell their shares, while firms have permanent access to the capital invested by the initial shareholders. By facilitating trade, stock markets reduce liquidity risk. As stock market transaction costs fall, more investment occurs in illiquid, high-return projects. If illiquid projects enjoy sufficiently large externalities, then greater stock market liquidity induces faster steady-state growth.

Financial intermediaries may also enhance liquidity, reduce liquidity risk, and influence economic growth. Banks can offer liquid deposits to savers and undertake a mixture of liquid, low-return investments to satisfy demands on deposits and illiquid, high-return investments. By providing demand deposits and choosing an appropriate mixture of liquid and illiquid investments, banks provide complete insurance to savers against liquidity risk while simultaneously facilitating long-run investments in high-return projects. Banks replicate the equilibrium allocation of capital that exists with observable shocks. Turning back to growth, Bencivenga and Smith (1991) show that, by eliminating liquidity risk, banks can increase investment in the high-return, illiquid asset and therefore accelerate growth.

Financial systems can also promote the accumulation of human capital (Jacoby, 1994). In particular, financial arrangements may facilitate borrowing for the accumulation of skills. If human capital accumulation is not subject to diminishing returns on a social level, financial arrangements that ease human capital creation help accelerate economic growth (Galor and Zeira, 1993).

\section{Pooling of Savings}

Mobilization-pooling-is the costly process of agglomerating capital from disparate savers for investment. Mobilizing savings involves (i) overcoming the transaction costs associated with collecting savings from different individuals and (ii) overcoming the informational asymmetries associated with making savers feel comfortable in relinquishing control of their savings. Indeed, much of Carosso's (1970) history of Investment Banking in America is a description of the diverse costs associated with raising capital in the United States during the nineteenth and twentieth centuries.

To economize on the costs associated with multiple bilateral contracts, pooling may also occur through intermediaries, where thousands of investors entrust their wealth to intermediaries that invest in hundreds of firms (Sirri and Tufano, 1995, p. 83). For this to occur, "mobilizers" have to convince savers of the soundness of the investments (Boyd and Smith, 1992). Toward this end, intermediaries worry about establishing stellar reputations, so that savers feel comfortable about entrusting their savings to the intermediary (Lamoreaux, 1994). 
Financial systems that are more effective at pooling the savings of individuals can profoundly affect economic development by increasing savings, exploiting economies of scale, and overcoming investment indivisibilities. Besides the direct effect on capital accumulation, better savings mobilization can improve resource allocation and boost technological innovation. Without access to multiple investors, many production processes would be constrained to economically inefficient scales (Sirri and Tufano, 1995). Furthermore, many endeavors require an enormous injection of capital that is beyond the means or inclination of any single investor. Bagehot (1873, p. 3-4) argued that a major difference between England and poorer countries was that in England the financial system could mobilize resources for "immense works." Thus, good projects would not fail for lack of capital. Bagehot was very explicit in noting that it was not the national savings rate per se, it was the ability to pool society's resources and allocate those savings toward the most productive ends. Furthermore, mobilization frequently involves the creation of small denomination instruments. These instruments provide opportunities for households to hold diversified portfolios (Sirri and Tufano, 1995).

\section{Easing Exchange}

Financial arrangements that lower transaction costs can promote specialization, technological innovation, and growth. The links between facilitating transactions, specialization, innovation, and economic growth were core elements of Adam Smith's (1776) Wealth of Nations. He argued that division of laborspecialization-is the principal factor underlying productivity improvements. With greater specialization, workers are more likely to invent better machines or production processes:

Men are much more likely to discover easier and readier methods of attaining any object, when the whole attention of their minds is directed towards that single object, than when it is dissipated among a great variety of things. (Smith, 1776, p. 3)

Smith focused on the role of money in lowering transaction costs, permitting greater specialization, and fostering technological innovation. Information costs, however, may also motivate the emergence of money. Since it is costly to evaluate the attributes of goods, barter exchange is very costly. Thus, an easily recognizable medium of exchange may arise to facilitate exchange (King and Plosser, 1986; Williamson and Wright, 1994). The drop in transaction and information costs is not necessarily a one-time fall when economies move to money, however. Transaction and information costs may continue to fall through financial innovation.

Greenwood and Smith (1996) have modeled the connections between exchange, specialization, and innovation. More specialization requires more transactions. Since each transaction is costly, financial arrangements that lower transaction costs will facilitate greater specialization. In this way, markets that 
promote exchange encourage productivity gains. There may also be feedback from these productivity gains to financial market development. If there are fixed costs associated with establishing markets, then higher income per capita implies that these fixed costs are less burdensome as a share of per capita income. Thus, economic development can spur the development of financial markets.

\section{Finance and Growth: Evidence}

\section{Cross-Country Studies: Financial Intermediaries}

We first examine the application of broad cross-country growth regressions to the study of finance and growth. These studies aggregate economic growth over long periods, a decade or more, and assess the relationship between long-run growth and measures of financial development. King and Levine (1993a,b,c) build on earlier cross-country work by Goldsmith (1969). In particular, King and Levine (1993a,b,c) more than double Goldsmith's (1969) sample of countries, study growth over a 30-year horizon, and systematically control for many possible determinants of economic growth such as initial income, educational attainment, inflation, black market exchange rate premia, government spending, openness to trade, and political instability. Furthermore, they examine whether financial development is associated with productivity growth and capital accumulation, which are two channels through which finance may influence economic growth.

King and Levine (1993b, henceforth KL) study 77 countries over the period 1960-89. To measure financial development, KL focus on DEPTH, which equals the size of the financial intermediary sector. It equals the liquid liabilities of the financial system (currency plus demand and interest-bearing liabilities of banks and nonbank financial intermediaries) divided by GDP. An important weakness with this measure of financial development is that DEPTH measures the size of the financial intermediary sector. It may not, however, represent an accurate proxy for the functioning of the financial system. It may not proxy for how well banks research firms, exert corporate control, or provide risk management services to clients. KL experiment with alternative measures of financial development that are designed to gauge who is conducting credit allocation (that is, whether it is banks or the government), and to where the credit is flowing (that is, to the private sector or to the government and state-owned enterprises). They obtain similar results with these alternative indicators of financial development. (Also, see La Porta et al. 2001.)

KL assess the strength of the empirical relationship between DEPTH averaged over the 1960-89 period and three growth indicators also averaged over the 1960-89 period, G. The three growth indicators are as follows: (i) the average rate of real per capita GDP growth, (ii) the average rate of growth in the capital stock per person, and (iii) total productivity growth, which is a "Solow 
residual" defined as real per capita GDP growth minus (0.3) times the growth rate of the capital stock per person. The analyses include a matrix of conditioning information, $X$, that controls for other factors associated with economic growth (such as income per capita, education, political stability, indicators of exchange rate, trade, fiscal, and monetary policy). KL estimated the following regressions:

$$
G(j)=a+b \mathrm{DEPTH}+c X+u
$$

Adapted from KL, table 1 indicates that there is a statistically significant and economically large relationship between DEPTH and (i) long-run real per capita growth, (ii) capital accumulation, and (iii) productivity growth. The coefficient on DEPTH implies that a country that increased DEPTH from the mean of the slowest-growing quartile of countries $(0.2)$ to the mean of the fastest-growing quartile of countries (0.6) would have increased its per capita growth rate by almost 1 percent per year. This is large. The difference between the slowestgrowing 25 percent of countries and the fastest-growing quartile of countries is about 5 percent per year over this 30 -year period. Thus, the rise in DEPTH alone eliminates 20 percent of this growth difference. The illustrative example, however, ignores causality and the issue of how to increase DEPTH.

Table 1: Growth and Financial Intermediary Development, 1960-89

\begin{tabular}{|c|c|c|c|}
\hline Dependent Variable & Depth & Bank & Privy \\
\hline \multirow[t]{2}{*}{ Real per Capita GDP Growth } & $2.4^{* *}$ & $3.2^{* *}$ & $3.2^{* *}$ \\
\hline & $(0.007)$ & $(0.005)$ & $(0.002)$ \\
\hline $\mathrm{R}^{2}$ & 0.50 & 0.50 & 0.52 \\
\hline \multirow[t]{2}{*}{ Real per Capita Capital Growth } & $2.2^{* *}$ & $2.2^{* *}$ & $2.5^{\star *}$ \\
\hline & $(0.006)$ & $(0.008)$ & $(0.007)$ \\
\hline $\mathrm{R}^{2}$ & 0.65 & 0.62 & 0.64 \\
\hline \multirow[t]{2}{*}{ Productivity Growth } & $1.8^{* *}$ & $2.6^{* *}$ & $2.5^{\star *}$ \\
\hline & $(0.026)$ & $(0.010)$ & $(0.006)$ \\
\hline $\mathrm{R}^{2}$ & 0.42 & 0.43 & 0.44 \\
\hline \multicolumn{4}{|c|}{$\begin{array}{l}\text { Source: King and Levine (1993b), Table VII. } \\
{ }^{*} \text { Significant at the } 0.10 \text { level, }{ }^{* *} \text { significant at the } 0.05 \text { level (p-values in parentheses). }\end{array}$} \\
\hline \multicolumn{4}{|c|}{$\begin{array}{l}\text { Variable definitions: } \\
\text { Depth = Liquid Liabilities/GDP. } \\
\text { Bank = Deposit bank domestic credit/(deposit bank domestic credit + central bank domestic credit). } \\
\text { Privy = Gross claims on the private sector/GDP. } \\
\text { Productivity Growth = Real per capita GDP growth }-(0.3) \times(\text { Real per capita Capital growth). }\end{array}$} \\
\hline \multicolumn{4}{|c|}{$\begin{array}{l}\text { Other explanatory variables included in each of the nine regression results reported above: } \\
\text { Logarithm of initial income, logarithm of initial secondary school enrollment, ratio of government consumption } \\
\text { expenditures to GDP, inflation rate, and ratio of exports plus imports to GDP. }\end{array}$} \\
\hline \multicolumn{4}{|c|}{$\begin{array}{l}\text { Notes: King and Levine (1993b) define } 2 \text { percent growth as } 0.02 \text {. For comparability with subsequent tables, we } \\
\text { have redefined } 2 \text { percent growth as } 2.00 \text { and adjusted the coefficients by a factor of } 100 \text {. }\end{array}$} \\
\hline
\end{tabular}


Table 2: Growth and Initial Financial Depth, 1960-89

\begin{tabular}{lc}
\hline Dependent Variable & Depth in 1960 \\
\hline Real per Capita GDP Growth, 1960-89 & $2.8^{* *}$ \\
$\mathrm{R}^{2}$ & $(0.001)$ \\
& 0.61 \\
Real per Capita Capital Growth, 1960-89 & $1.9^{* *}$ \\
$\mathrm{R}^{2}$ & $(0.001)$ \\
Productivity Growth, 1960-89 & 0.63 \\
$\mathrm{R}^{2}$ & $2.2^{* *}$ \\
\hline
\end{tabular}

Sources: King and Levine (1993b), Table VIII; and Levine (1997), Table 3.

* Significant at the 0.10 level, ${ }^{* *}$ significant at the 0.05 level ( $p$-values in parentheses). Observations: 57.

Variable definitions:

Depth = Liquid Liabilities/GDP

Productivity Growth $=$ Real per capita GDP growth $-(0.3) \times($ Real per capita Capital growth).

Other explanatory variables included in each of the regression results reported above:

Logarithm of initial income, logarithm of initial secondary school enrollment, ratio of government consumption expenditures to GDP, inflation rate, and ratio of exports plus imports to GDP.

Notes: King and Levine (1993b) and Levine (1997) define 2 percent growth as 0.02 . For comparability with subsequent tables, we have redefined 2 percent growth as 2.00 and adjusted the coefficients by a factor of 100 .

KL also examine whether the value of financial depth in 1960 predicts the rate of economic growth, capital accumulation, and productivity growth over the next 30 years. As shown in table 2, the regressions indicate that financial depth in 1960 is a good predictor of subsequent rates of economic growth, physical capital accumulation, and economic efficiency improvements over the next 30 years even after controlling for income, education, and measures of monetary, trade, and fiscal policy. Thus, finance does not simply follow growth; financial development predicts long-run growth.

Although improving on past work, there are methodological and interpretation problems with the KL analyses. As noted in the Introduction, the proxy measures for financial development-DEPTH and the alternative measures-do not directly measure the ability of the financial system to (i) overcome information asymmetries and funnel credit to worthy firms, (ii) monitor managers effectively and exert corporate governance efficiently, (iii) provide risk management services, or (iv) facilitate exchange and the pooling of savings. This lowers the confidence one has in interpreting the results as establishing a link running from financial development to economic growth. Also, although KL show that finance predicts growth, they do not deal formally with the issue of causality. Finally, KL only focus on one segment of the financial system, banks. They do not incorporate measures of other components of national financial systems. 


\section{Cross-Country Studies: Stock Markets and Banks}

Following Atje and Jovanovic (1993), Levine and Zervos (1998, henceforth LZ) add measures of stock market and banking development to cross-country studies of growth. Thus, they simultaneously examine two components of the financial system: banks and equity markets. This provides information on the independent impact of stock markets and banks on economic growth. Thus, these analyses help policy makers set reform priorities and influence debates on the comparative importance of different segments of the financial sector (Demirgüç-Kunt and Levine, 2001).

LZ construct numerous measures of stock market development to assess the relationship between stock market development and economic growth, capital accumulation, and productivity. In this paper, we focus on one of the LZ liquidity indicators: the turnover ratio. This equals the total value of shares traded on a country's stock exchanges divided by stock market capitalization (the value of listed shares on the country's exchanges). The turnover ratio measures trading relative to the size of the market. All else equal, therefore, differences in trading frictions will influence the turnover ratio. LZ confirm their results using an assortment of stock market development indicators. ${ }^{2}$

There are difficulties in measuring liquidity, however. First, LZ do not measure the direct costs of conducting equity transactions. LZ simply measure trading, which may reflect differences in the arrival of news and how heterogeneous agents interpret this information. Thus, although we would like a proxy of the ease of trading at posted prices, the data provide only a measure of actual transactions. Second, stock markets may do more than provide liquidity. For instance, stock markets may provide mechanisms for hedging and trading the idiosyncratic risk associated with individual projects, firms, industries, sectors, and countries. Thus, focusing on liquidity may omit important services provided by equity markets and therefore mis-measure stock market development. Third, the turnover ratio measures domestic stock transactions on a country's national stock exchanges. The physical location of the stock market, however, may not necessarily matter for the provision of liquidity. This measurement problem will increase if economies become more financially integrated and firms list and issue shares on foreign exchanges.

The turnover ratio exhibits substantial cross-country variability. Very active markets such as Japan and the United States had turnover ratios of almost 0.5

\footnotetext{
${ }^{2}$ Levine and Zervos (1998) examine three additional measures of liquidity. First, the value traded ratio equals the total value of domestic stocks traded on domestic exchanges as a share of GDP. This measures trading relative to the size of the economy. The next two measures of liquidity measure trading relative to stock price movements: (i) the value traded ratio divided by stock return volatility, and (ii) the turnover ratio divided by stock return volatility. They also examine a measure of stock market integration. Although a vast literature examines the pricing of risk, there exists very little empirical evidence that directly links risk diversification services with long-run economic growth. LZ do not find a strong link between economic growth and the ability of investors to diversify risk internationally.
} 
Table 3: Stock Market and Bank Development Predict Growth, 1976-93

\begin{tabular}{lccc}
\hline & \multicolumn{2}{c}{ Independent Variables (1976) } \\
\cline { 2 - 4 } Dependent Variable (1976-93) & Bank Credit & Turnover & $\mathbf{R}^{\mathbf{2}}$ \\
\hline Real per Capita GDP Growth & $1.31^{* *}$ & $2.69^{* *}$ & 0.50 \\
& $(0.022)$ & $(0.005)$ & \\
Real per Capita Capital Growth & & & \\
& $1.48^{* *}$ & $2.22^{* *}$ & 0.51 \\
Productivity Growth & $(0.025)$ & $(0.024)$ & \\
& & & \\
\end{tabular}

Source: Levine and Zervos (1998), Table 3.

${ }^{*}$ Significant at the 0.10 level, ${ }^{* *}$ significant at the 0.05 level. (p-values in parentheses).

Observations: 42 for the real per capita GDP growth regression and 41 for the others.

Variable definitions:

Bank Credit = Bank credit to the private sector / GDP in 1976 or the closest date with data.

Turnover $=$ Value of the trades of domestic shares on domestic exchanges as a share of market capitalization of domestic shares in 1976 or the closest date with data.

Productivity Growth $=$ Real per capita GDP growth $-(0.3) \times($ Real per capita Capital growth $)$

Other explanatory variables included in each of regression results reported above:

Logarithm of initial income, logarithm of initial secondary school enrollment, ratio of government consumption expenditures to GDP, inflation rate, black market exchange rate premium, and frequency of revolutions and coups.

Notes: Levine and Zervos define 2 percent growth as 0.02 . For comparability with subsequent tables, we have redefined 2 percent growth as 2.00 and adjusted the coefficients by a factor of 100 .

during the period 1976-93. Less liquid markets, such as Bangladesh, Chile, and Egypt, had turnover ratios of 0.06 or less.

As summarized in table 3, LZ find that the initial level of stock market liquidity and the initial level of banking development (Bank Credit) are positively and significantly correlated with future rates of economic growth, capital accumulation, and productivity growth over the next 18 years, even after controlling for initial income, schooling, inflation, government spending, the black market exchange rate premium, and political stability. To measure banking sector development, LZ use Bank credit, which equals bank credit to the private sector as a share of GDP. This measure of banking development excludes credit issued by the government and the central bank and excludes credits issued to the government and public enterprises. LZ argue that their banking development indicator is better than KL because nongovernmental financial intermediaries that are allocating credit to private firms are more likely to improve the efficiency of credit allocation and the monitoring of firms than intermediaries that are allocating money to the government and public enterprises.

These results are consistent with models that emphasize that stock market liquidity facilitates long-run growth (Levine, 1991; Bencivenga et al., 1995) and not supportive of models that emphasize the negative aspects of stock market liquidity (Bhide, 1993). Furthermore, the results do not lend much support to models that emphasize the tensions between bank-based and market-based 
systems. Rather, the results suggest that stock markets provide different financial functions from those provided by banks, or else they would not both enter the growth regression significantly.

The sizes of the coefficients are economically meaningful. For example, the estimated coefficient implies that a one-standard-deviation increase in initial stock market liquidity (0.30) would increase per capita GDP growth by 0.80 percentage points per year $\left(2.7^{*} 0.3\right)$. Accumulating over 18 years, this implies real GDP per capita would have been over 15 percentage points higher by the end of the sample. Similarly, the estimated coefficient on Bank Credit implies a correspondingly large growth effect. That is, a one-standard-deviation increase in Bank Credit (0.5) would increase growth by 0.7 of a percentage point per year $\left(1.3^{*} 0.5\right)$. Taken together, the results imply that if a country had increased both stock market liquidity and bank development by one standard deviation, then by the end of the 18-year sample period, real per capita GDP would have been almost 30 percent higher and productivity would have been almost 25 percent higher.

Critically for policy makers, LZ do not find that stock market size, as measured by market capitalization divided by GDP, is robustly correlated with growth. Simply listing on the national stock exchange does not necessarily foster resource allocation. Rather, it is the ability to trade ownership of the economy's productive technologies that influences resource allocation and growth.

Although LZ incorporate stock markets into the analysis of economic growth, there are problems. First, they do not deal formally with the issue of causality. Second, although LZ include stock markets, they exclude other components of the financial sector such as bond markets and the financial services provided by nonfinancial firms. Third, as discussed above, the turnover ratio may not accurately measure the ability to trade shares and may miss other important services provided by equity markets.

\section{Using Instrumental Variables to Deal with Simultaneity Bias}

To assess whether the finance-growth relationship is driven by simultaneity bias, recent research uses instrumental variables to extract the exogenous component of financial development. To do this, one needs instrumental variables that explain cross-country differences in financial development but are uncorrelated with economic growth beyond their link with financial development. Then, one can use standard instrumental variable procedures to examine the financegrowth relationship while formally controlling for endogeneity.

Levine (1998, 1999) and Levine, Loayza, and Beck (2000) use the La Porta, Lopez-de-Silanes, Shleifer, and Vishny (henceforth LLSV, 1998) measures of legal origin as instrumental variables. In particular, LLSV show that legal originwhether a country's commercial/company law derives from British, French, German, or Scandinavian law-importantly shapes national approaches to laws concerning creditors and the efficiency with which those laws are enforced. Since 
finance is based on contracts, legal origins that produce laws that protect the rights of external investors and enforce those rights effectively will do a correspondingly better job at promoting financial development. Indeed, LLSV trace the effect of legal origin to laws and enforcement and then to the development of financial intermediaries. Since most countries obtained their legal systems through occupation and colonization, the legal origin variables may be plausibly treated as exogenous.

Formally, consider the generalized method of moments (GMM) regression:

$$
G(j)=a+b F(i)+c X+u
$$

$G(j)$ is real per capita GDP growth over the period 1960-95. The legal origin indicators, $Z$, are used as instrumental variables for the measures of financial development, $F(i)$. $X$ is treated as an included exogenous variable.

The validity of the instrumental variables, the legal origin dummy variables, requires that they are uncorrelated with the error term, $u$ : that is, they may affect growth only through the financial development indicators and the variables in the conditioning information set, $X$. We test the null hypothesis that the instrumental variables are uncorrelated with the error term using Hansen's (1982) test of the overidentifying restrictions (OIR-test). If the regression specification "passes" the test, then we cannot reject the statistical and economic significance of the estimated coefficient on financial intermediary development as indicating an effect running from financial development to per capita GDP growth.

In using instrumental variables, Levine, Loayza, and Beck (2000) and Beck, Levine, and Loayza (2000) also develop a new measure of overall financial development. The new measure, Private Credit, equals the value of credits by financial intermediaries to the private sector divided by GDP. The measure (i) isolates credit issued to the private sector; (ii) excludes credit issued to governments, government agencies, and public enterprises; and (iii) excludes credits issued by central banks. Unlike the LZ Bank Credit measure, Private Credit includes credits issued by financial intermediaries that are not classified as deposit money banks by the International Monetary Fund.

As shown in table 4 (IV-Cross-Country), Beck, Levine, and Loayza (2000) find a very strong connection between the exogenous component of financial intermediary development and long-run economic growth when using crosscountry instrumental variables. They also show that the exogenous component of financial development is linked with both capital accumulation and productivity growth. Using various conditioning information sets - that is, different $X^{\prime}$ s - the results still hold. Furthermore, the data do not reject Hansen's (1982) test of the overidentifying restrictions. Also, Levine (2000) confirms these findings using the La Porta et al. (2001) measure of privately owned banks. Thus, the exogenous 
component of privately owned banks is positively associated with economic growth.

These results suggest an economically large impact of financial development on growth. For example, India's value of Private Credit over the period 1960-95 was 19.5 percent of GDP, while the mean value for developing countries was 25 percent of GDP. The estimated coefficient suggests that an exogenous improvement in Private Credit in India that had pushed it to the sample mean for developing countries would have accelerated real per capita GDP growth by an additional 0.6 of a percentage point per year. These types of conceptual experiments must be treated as illustrative because they do not account for how to increase financial intermediary development.

Table 4: Growth, Productivity Growth, and Capital Accumulation, Panel GMM and OLS, 1960-95

\begin{tabular}{|c|c|c|c|c|c|c|}
\hline $\begin{array}{l}\text { Estimation } \\
\text { Procedure }\end{array}$ & $\begin{array}{l}\text { Private } \\
\text { Credit }\end{array}$ & Countries & Obs. & OIR-test ${ }^{1}$ & $\begin{array}{c}\text { Sargan test }{ }^{2} \\
\text { (p-value) }\end{array}$ & $\begin{array}{l}\text { Serial correlation } \\
\text { test }^{3} \text { ( } p \text {-value) }\end{array}$ \\
\hline \multicolumn{7}{|c|}{ 1. Dependent Variable: Real per Capita GDP Growth } \\
\hline \multirow[t]{2}{*}{ IV-Cross-Country } & $2.22^{* *}$ & 63 & 63 & 0.577 & & \\
\hline & $(0.003)$ & & & & & \\
\hline \multirow[t]{2}{*}{ GMM-Panel } & $2.40^{* *}$ & 77 & 365 & & 0.183 & 0.516 \\
\hline & $(0.001)$ & & & & & \\
\hline \multicolumn{7}{|c|}{ 2. Dependent Variable: Productivity Growth } \\
\hline \multirow[t]{2}{*}{ IV-Cross-Country } & $1.50^{\star *}$ & 63 & 63 & 2.036 & & \\
\hline & $(0.004)$ & & & & & \\
\hline \multirow[t]{2}{*}{ GMM-Panel } & $1.33^{* *}$ & 77 & 365 & & 0.205 & 0.772 \\
\hline & $(0.001)$ & & & & & \\
\hline \multicolumn{7}{|c|}{ 3. Dependent Variable: Capital per Capita Growth } \\
\hline \multirow[t]{2}{*}{ IV-Cross-Country } & $2.83^{* *}$ & 63 & 63 & 6.750 & & \\
\hline & $(0.006)$ & & & & & \\
\hline \multirow[t]{2}{*}{ GMM-Panel } & $3.44^{* *}$ & 77 & 365 & & 0.166 & 0.014 \\
\hline & $(0.001)$ & & & & & \\
\hline
\end{tabular}

Source: Beck, Levine, and Loayza (2000).

1. The null hypothesis is that the instruments used are not correlated with the residuals from the respective regression. Critical values for OIR-Test ( 2 d.f.): $10 \%=4.61 ; 5 \%=5.99$.

2. The null hypothesis is that the instruments used are not correlated with the residuals from the respective regression.

3. The null hypothesis is that the errors in the first-difference regression exhibit no second-order serial correlation

* Significant at the 0.10 level, ** significant at the 0.05 level ( $p$-values in parentheses).

IV-Cross-Country: Cross-country instrumental variables with legal origin as instruments, estimated using GMM. GMM-Panel: Dynamic panel (5-year averages) generalized method of moments using system estimator.

Other explanatory variables:

Logarithm of initial income per capita, average years of schooling.

Private Credit: Logarithm (credit by deposit money banks and other financial institutions to the private sector divided by GDP.) 
Although these analyses confront the causality issue, problems remain. Besides the problems noted earlier with constructing accurate measures of financial development, these cross-country instrumental variable analyses only consider the endogenous determination of the financial development. They treat the other explanatory variables as exogenous. Furthermore, the cross-country instrumental variable studies do not simultaneously consider the independent role of equity markets.

\section{Panel Studies of Finance and Growth}

\section{Why Use Panel Techniques?}

In light of the problems associated with purely cross-country growth regressions, Levine, Loayza, and Beck (2000, henceforth LLB) use a GMM estimator developed for panel data (Arellano and Bond, 1991; Arellano and Bover, 1995). In comparison to purely cross-country approaches, the panel approach has three important advantages and one particular disadvantage. To see these, consider the panel regression specified as follows:

$$
y(i, t)=a X^{1}(i, t)+b X^{2}(i, t)+C(i)+T(t)+u(i, t)
$$

where $y$ represents growth, $X^{1}$ represents a set of lagged explanatory variables and $X^{2}$ a set of contemporaneous explanatory variables, $C$ is an unobserved country-specific effect, $T$ is a time-specific effect, $u$ is the time-varying error term, and $i$ and $t$ represent country and (five-year) time period, respectively.

The first benefit from moving to a panel is the ability to exploit the timeseries and cross-sectional variation in the data. LLB construct a panel that consists of data for 77 countries over the period 1960-95. The data are averaged over seven nonoverlapping five-year periods. Moving to a panel incorporates the variability of the time-series dimension, which allows the panel approach to exploit substantial additional variability.

A second benefit from moving to a panel is that in the purely cross-sectional regression, the unobserved country-specific effect is part of the error term so that correlation between $C(i)$ and the explanatory variables results in biased coefficient estimates. ${ }^{3}$ To control for the presence of unobserved country-specific effects, Arellano and Bond (1991) propose to first-difference the regression equation to eliminate the country-specific effect and then use instrumental variables to control for endogeneity. This approach eliminates biases due to country-specific omitted variables.

The third benefit from using a panel is that it overcomes the problem that the pure cross-country instrumental variable work does not control for the potential endogeneity of all the regressors. This can lead to inappropriate

\footnotetext{
${ }^{3}$ Furthermore, if the lagged dependent variable is included in $X^{1}$ (which is the norm in crosscountry regressions), then the country-specific effect is certainly correlated with $X^{1}$.
} 
inferences on the coefficient on financial development. The panel estimator uses instruments based on previous realizations of the explanatory variables to consider the potential endogeneity of the other regressors.

An important disadvantage from to moving to panel data is that it means employing data averaged over five-year periods. Yet, we are seeking to assess the connection between financial development and long-run growth. To the extent that five years does not adequately proxy for long-run growth, the panel methods may be less precise in assessing the finance growth relationship than methods based on lower frequency data.

\section{Results with Financial Intermediation}

LLB use panel techniques to study the relationship between financial intermediary development and growth, while Beck, Levine, and Loayza (2000) extend this work to evaluate the relationship between financial development and the sources of growth-that is, productivity growth and physical capital accumulation. They use many indicators of financial intermediary development and various conditioning information sets to assess robustness (Levine and Renelt, 1992). Table 4 summarizes these results using the Private Credit measure of financial development described above.

Table 4 indicates a positive relationship between the exogenous component of financial development and economic growth, productivity growth, and capital accumulation. The regressions pass the standard specification tests for panel regressions. Remarkably, the coefficient estimates for the panel estimates are very similar to those obtained using pure cross-sectional instrumental variables. Thus, the large, positive relationship between economic growth and Private Credit does not appear to be driven by simultaneity bias, omitted countryspecific effects, or other problems plaguing cross-country growth regressions. ${ }^{4}$

\section{Stock Markets, Banks, and Growth Revisited}

Rousseau and Wachtel (2000) extend the Levine and Zervos (1998) study of stock markets, banks, and growth to a panel context. They use annual data and the panel difference estimator proposed by Arellano and Bond (1991). Thus, they jointly study the impact of bank and equity markets on economic growth.

Beck and Levine (2002) build on Rousseau and Wachtel (2000). Beck and Levine (i) use data averaged over five-year periods to abstract from businesscycle fluctuations, (ii) employ more recent panel procedures that avoid biases associated with difference, and (iii) extend the sample through 1998, which mitigates the potential effect of the Asian stock market boom in the 1990s on the results.

\footnotetext{
${ }^{4}$ Beck, Levine, and Loayza (2000) go on to argue that the finance-capital accumulation link is not robust to alternative specifications, but financial development is robustly linked with both economic growth and productivity growth.
} 
Table 5 indicates that the exogenous component of both stock market development and bank development help predict economic growth. Based on Beck and Levine (2002), table 5 also presents simple OLS regressions. As shown, the coefficient estimates from the two methods are very similar. The panel procedure passes the standard specification tests, which increases confidence in the assumptions underlying the econometric methodology. Although not shown, Beck and Levine (2002) find that stock market capitalization is not closely associated with growth, which confirms the earlier results by Levine and Zervos (1998). Thus, it is not listing per se that is important for growth; rather, it is the ability of agents to exchange ownership claims on an economy's productive technologies that matters.

The table 5 estimates are economically meaningful and consistent with magnitudes obtained using different methods. If Mexico's Turnover Ratio had been at the average of the OECD countries (68 percent) instead of the actual 36 percent during the period 1996-98, it would have grown 0.6 of a percentage point faster per year. Similarly, if its Bank Credit had been at the average of all OECD countries (71 percent) instead of the actual 16 percent, it would have grown 0.6 of a percentage point faster per year.

Table 5: Stock Markets, Banks, and Growth: Panel GMM and OLS, 1975-98

\begin{tabular}{|c|c|c|c|c|c|c|}
\hline $\begin{array}{l}\text { Estimation } \\
\text { Procedure }\end{array}$ & $\begin{array}{l}\text { Bank } \\
\text { Credit }\end{array}$ & Turnover & Countries & Obs. & $\begin{array}{c}\text { Sargan } \\
\text { test }^{1} \\
\text { (p-value) }\end{array}$ & $\begin{array}{l}\text { Serial } \\
\text { correlation } \\
\text { test }^{2}(p- \\
\text { value) }\end{array}$ \\
\hline \multicolumn{7}{|c|}{ Dependent Variable: Real per Capita GDP Growth } \\
\hline \multirow[t]{2}{*}{ OLS-Cross-Country } & $1.47^{* *}$ & $0.79^{* *}$ & 40 & & & \\
\hline & $(0.001)$ & $(0.025)$ & & & & \\
\hline \multirow[t]{2}{*}{ GMM-Panel } & $1.76^{* *}$ & $0.96^{\star *}$ & 40 & 146 & 0.488 & 0.60 \\
\hline & $(0.001)$ & $(0.001)$ & & & & \\
\hline
\end{tabular}

Source: Beck and Levine (2004), Tables 2 and 3.

* Significant at the 0.10 level, ${ }^{* *}$ significant at the 0.05 level ( $p$-values in parentheses).

OLS: Ordinary Least Squares with heteroskedasticity consistent standard errors.

GMM: Dynamic panel Generalized Method of Moments using system estimator.

1. The null hypothesis is that the instruments used are not correlated with the residuals.

2. The null hypothesis is that the errors in the first-difference regression exhibit no second-order serial correlation.

Bank Credit $=$ logarithm (credit by deposit money banks to the private sector as a share of GDP.)

Turnover = logarithm (Value of the trades of domestic shares on domestic exchanges as a share of market capitalization of domestic shares)

Other explanatory variables included in each of the regression results reported above:

Logarithm of initial income and logarithm of initial secondary school enrollment. 
These results suggest that the exogenous component of both bank and stock market development have an economically large impact on economic growth. Note, however, using quarterly data and vector autoregressive techniques, Arestis, Demetriades, and Luintel (2000) find that the economic effect of stock market liquidity on growth is positive and significant, but smaller economically than that found in Levine and Zervos (1998), Rousseau and Wachtel (2000), and Beck and Levine (2002). Although differences in data frequency, country coverage, sample period, and econometric technique may account for the differences, future works needs to clarify the economic impact of stock market development on economic growth.

\section{Microeconomic Studies of Finance and Growth}

Industry-level and firm-level data have also been brought to bear on the question of whether financial development promotes economic growth. By circumventing weaknesses with cross-country and panel studies, the microeconomic research seeks to resolve causality issues and to document in greater detail the mechanisms, if any, through which finance influences economic growth.

\section{Industry-Level Studies}

In a very influential study, Rajan and Zingales (henceforth RZ, 1998) use industry-level data to study the mechanisms through which financial development may influence economic growth and to deal rigorously with causality issues. They argue that better-developed financial systems ameliorate market frictions that make it difficult for firms to obtain external finance. Thus, industries that are naturally heavy users of external finance should benefit disproportionately more from greater financial development than industries that are not naturally heavy users of external finance. If researchers can identify those industries that rely heavily on external finance in an economy with few market frictions-that is, "naturally heavy users" of external finance-then this establishes a natural test: Do industries that are naturally heavy users of external finance grow faster in economies with better developed financial systems? If they do, then this supports the view that financial development spurs growth by facilitating the flow of external finance.

RZ work under three maintained assumptions: (i) financial markets in the United States are relatively frictionless; (ii) in a frictionless financial system, technological factors influence the degree to which an industry uses external finance; and (iii) the technological factors influencing external finance are reasonably constant across countries. RZ use the external financing of industries in the United States as a benchmark of the external financing needs of industries in a comparatively frictionless financial system. They, then assess whether industries that are naturally heavy users of external finance grow comparatively faster in countries that are more financially developed. 
RZ develop methods to examine whether industries that are naturally heavy users of external finance grow faster in financially developed economies. Consider the equation.

$$
\operatorname{Growth}(i, k)=a C+b I+\operatorname{cShare}(i, k)+d\left[\operatorname{External}(k)^{*} F D(i)\right]+u(i, k)
$$

Growth $(i, k)$ is the average annual growth rate of value added in industry $k$ and country $i$, over the period 1980-90. $C$ and $I$ are matrices of country and industry dummies for all countries and industries, respectively. Share $(i, k)$ is the share of industry $k$ in manufacturing in country $i$ in 1980. External $(k)$ is the fraction of capital expenditures not financed with internal funds for U.S. firms in the industry $k$ between 1980-90. $F D(i)$ is an indicator of financial development for country $i$. RZ interact the external dependence of an industry (External) with financial development (FD), where the estimated coefficient on the interaction, $d$, is the focus of their analysis. Thus, if $d$ is significant and positive, then this implies that an increase in financial development $(F D)$ will induce a bigger impact on industrial growth $(G r o w t h(i, k))$ if this industry relies heavily on external finance (External $(k)$ ) than if this industry is not a naturally heavy user of external finance.

This approach allows RZ (i) to study a particular mechanism, external finance, through which finance operates rather than simply assessing links between finance and growth, and (ii) to exploit within-country differences concerning industries.

RZ use data on 36 industries across 41 countries. To measure financial development, RZ examine (i) total capitalization, which equals the summation of stock market capitalization and domestic credit as a share of GDP, and (ii) accounting standards. As RZ discuss, there are problems with these measures. Stock market capitalization does not capture the actual amount of capital raised in equity markets. $\mathrm{RZ}$ use the accounting standards measure as a positive signal of the ease with which firms can raise external funds, while noting that it is not a direct measure external financing. Beck and Levine (2000) confirm the RZ findings using alternative measures of financial development.

As summarized in table 6, RZ find that the coefficient estimate for the interaction between external dependence and total capitalization measure, External $(k)^{*}$ Total Capitalization( $(i)$, is positive and statistically significant at the onepercent level. This implies that an increase in financial development disproportionately boosts the growth of industries that are naturally heavy users of external finance.

RZ note that the economic magnitude is large. Compare Machinery, which is an industry at the $75^{\text {th }}$ percentile of dependence (0.45), with Beverages, which has low dependence $(0.08)$ and is at the $25^{\text {th }}$ percentile of dependence. Now, consider Italy, which has high total capitalization $(0.98)$ at the $75^{\text {th }}$ percentile of the sample, and the Philippines, which is at the $25^{\text {th }}$ percentile of total capitalization with a value of 0.46 . Due to differences in financial development, the coefficient 
Table 6: Industry Growth and Financial Development

\begin{tabular}{|c|c|c|c|c|}
\hline $\begin{array}{c}\text { Share } i, k \text { of industry } k \\
\text { in country } i \text { in } 1980\end{array}$ & $\begin{array}{c}\text { External }_{k} \times \text { Total } \\
\text { Capitalization }_{i}\end{array}$ & $\begin{array}{l}\text { External }_{k} \times \\
\text { Accounting } \\
\text { Standards } s_{i}\end{array}$ & $\mathbf{R}^{2}$ & Observations \\
\hline \multicolumn{5}{|c|}{ Dependent Variable: Growth of value added of industry $k$ in country $i, 1980-90$} \\
\hline-0.912 & 0.069 & & 0.29 & 1217 \\
\hline$(0.246)$ & $(0.023)$ & & & \\
\hline $\begin{array}{l}-0.643 \\
(0.204)\end{array}$ & & $\begin{array}{l}0.155 \\
(0.034)\end{array}$ & 0.35 & 1067 \\
\hline
\end{tabular}

Source: Rajan and Zingales (1998), Table 4.

Notes:

The table above reports the results from the regression:

Growth $_{i, k}=\sum_{j} \alpha_{j}$ Country $_{j}+\sum_{l} \beta_{l}$ Industry $_{l}+\gamma$ Share $_{i, k}+\delta_{1}\left(\right.$ External $\left._{k} * F D_{i}\right)+\varepsilon_{i, k}$

Two regressions are reported corresponding to two values of $F D_{i}$, Total Capitalization and Account Standards respectively.

(Heteroskedasticity robust standard errors are reported in parentheses.)

External ${ }_{k}$ is the fraction of capital expenditures not financed with internal funds for U.S. firms in industry $k$ between 1980-90.

Total Capitalization is stock market capitalization plus domestic credit.

Accounting Standards is an index of the quality of corporate financial reports.

estimates predict that Machinery should grow 1.3 percent faster than Beverages in Italy in comparison to the Philippines. The actual difference is 3.4, so the estimated value of 1.3 is substantial. Thus, financial development has a big impact on industrial growth by facilitating external finance.

\section{Firm-Level Studies}

Demirgüç-Kunt and Maksimovic (henceforth DM, 1998) use firm-level data and test whether financial development influences the degree to which firms are constrained from investing in profitable growth opportunities. They focus on the use of long-term debt and external equity in funding firm growth. As in RZ, DM focuses on a particular mechanism through which finance influences growth: does greater financial development remove impediments to firm growth. In contrast to RZ, DM estimate the external financing needs of each individual firm in the sample.

Questioning the assumptions underlying RZ, DM argue that it is important to allow for differences in the amount of external financing needed by firms in the same industry in different countries. These differences may arise because firms in different countries employ different technologies, because profit rates may differ across countries, or because investment opportunities and demand may differ.

To control for differences in the need for external finance at the firm-level, DM calculate the rate at which each firm can grow using (i) only its internal funds and (ii) only its internal funds and short-term borrowing. They then compute the percentage of firms that grow at rates that exceed each of these two 
estimated rates. This yields estimates of the proportion of firms in each economy relying on external financing to grow.

For the largest publicly traded manufacturing firms in 26 countries, DM estimate a firm's potential growth rate using the textbook "percentage of sales" financial planning model (Higgins 1977). ${ }^{5}$ This approach relates a firm's growth rate of sales to its need for investment funds, based on three simplifying assumptions. First, the ratio of assets used in production to sales is constant. Second, the firm's profits per unit of sales are constant. Finally, the economic deprecation rate equals the accounting depreciation rate.

Based on these important maintained assumptions, DM compute the shortterm financed growth rate STFGt as the maximum growth rate that can be obtained if the firm reinvests all its earnings and obtains enough short-term external resources to maintain the ratio of its short-term liabilities to assets.

Then, DM calculate the proportion of firms whose growth rates exceed the estimate of the maximum growth rate that can be financed by relying only on internal and short-term financing, PROPORTION_FASTER. There is quite a bit of cross-country variation in the PROPORTION_FASTER. For instance, in Turkey, South Africa, and Pakistan, less than 30 percent of the firms have growth rates that exceed the estimate of the maximum growth rate that can be financed by relying only on internal and short-term financing. In contrast, in Japan, the Republic of Korea, Singapore, and Thailand, PROPORTION_FASTER is greater than 50 percent. Put differently, in these countries, more than half the firms require long-term financing to finance their growth according to the "percentage of sales" financial planning model.

To analyze whether financial development spurs firm growth, DM run the following cross-country regression regressions

$$
\text { PROPORTION_FASTER }=a+b F D(i, t)+c C V(i, t)+u(i, t)
$$

where $F D$ is a variety of measures of financial development, $C V$ is a set of control variables, and $u$ is the error term. To measure financial development, DM use (i) the ratio of market capitalization to GDP (Market Capitalization/GDP); (ii) Turnover, which equals the total value of shares traded divided by market capitalization; and (iii) Bank Assets/GDP, which equals the ratio of domestic assets of deposit banks divided by GDP. Thus, DM include all domestic assets of deposit banks, not just credit to the private sector. DM experiment with different combinations of control variables, including economic growth, inflation, the average market-to-book value of firms in the economy, government subsidies to firms in the economy, the net fixed assets divided by total assets of firms in the economy, the level real per capita GDP, and the law and order tradition of the economy.

\footnotetext{
${ }^{5}$ Beck, Demirgüç-Kunt, Levine, and Maksimovic (2001) confirm the findings using an extended sample.
} 
Table 7: Excess Growth of Firms and External Financing

\begin{tabular}{ccccc}
\hline Market Capitalization/GDP & Turnover & Bank Assets/GDP & Adj. $\mathbf{R}^{2}$ & Countries \\
\hline Dependent Variable: Proportion of firms that grow faster than their predicted growth rate ${ }^{1}$ \\
-0.106 & $0.311^{* * *}$ & $0.162^{* * *}$ & 0.48 & 26 \\
$(0.058)$ & $(0.072)$ & $(0.050)$ & \\
\hline
\end{tabular}

Source: Demirgüç-Kunt and Maksimovic (1998), Table V.

Notes:

White's heteroskedasticity consistent standard errors in parentheses.

*** indicates statistical significance at the 1 percent level.

1. The proportion of firms whose growth rates exceed the estimate of the maximum growth rate that can be financed by relying only on internal and short-term financing.

Market Capitalization/GDP: The value of domestic equities listed on domestic exchanges as a share of GDP.

Turnover: The total value of trades of domestic shares on domestic exchanges as a share of market capitalization.

Other regressors: rate of inflation, the law and order tradition of the economy, i.e., the extent to which citizens utilize existing legal system to mediate disputes and enforce contracts, growth rate of real GDP per capita, real GDP per capita, government subsidies to private industries and public enterprises as a share of GDP, and net fixes assets divided by total assets.

Time period: The dependent variable is averaged over the 1986-1991 period. All regressors are averaged over the $1980-85$ period, data permitting.

As summarized in table 7, DM find that both banking system development and stock market liquidity are positively associated with the excess growth of firms. Thus, in countries with high Turnover and high Bank Assets/GDP a larger proportion of firms is growing at a level that requires access to external sources of long-term capital, holding other things constant. Note, consistent with Levine and Zervos (1998), the size of the domestic stock markets is not related to the excess growth of firms. After conducting a wide array of robustness checks, DM conclude that the proportion of firms that grow at rates exceeding the rate at which each firm can grow with only retained earnings and short-term borrowing is positively associated with stock market liquidity and banking system size.

\section{Country Case Studies}

Dropping the cross-country dimension and focusing on an individual country often increases the confidence in the results by reducing potential biases due to measurement error and reducing concerns about omitted variables and endogeneity. In a study of individual regions of Italy, Guiso, Sapienza, and Zingales (2002) use a household dataset and examine the effect of differences in local financial development on economic activity across different regions. They find that local financial development enhances the probability that an individual starts a business, increases industrial competition, and promotes growth of firms. And these results are stronger for smaller firms that cannot easily raise funds outside of the local area. Another example is Haber's (1997) historical comparison of industrial and capital market development in Brazil, Mexico, and the United States between 1830 and 1930. He uses firm-level data to illustrate 
that international differences in financial development significantly affected the rate of industrial expansion.

Perhaps one of the cleanest ways of dealing with identification problems is to focus on a particular policy change in a specific country and evaluate its impact. One example of this approach is Jayaratne and Strahan's (1996) investigation of the impact of bank branch reform in individual states of the United States. Since early 1970s, U.S. states started relaxing impediments on their intrastate branching. Using a difference-in-difference methodology, Jayaratne and Strahan estimate the change in economic growth rates after branch reform relative to a control group of states that did not reform. They show that bank branch reform boosted bank-lending quality and accelerated real per capita growth rates. In another study Bertrand, Schoar, and Thesmar (2004) provide firm-level evidence from France that shows the impact of 1985 deregulation eliminating government intervention in bank lending decisions fostered greater competition in the credit market, inducing an increase in allocative efficiency across firms.

Of course focusing on individual country cases often raises the question how applicable the results are in different country settings. Nevertheless, these careful country-level analyses boost our confidence in the link between financial development and growth that is suggested by the cross-country studies. Unfortunately, many potential causal factors of development interest do not vary much within a country, and exogenous policy changes do not occur often enough.

\section{Summary and Qualifications}

Although still subject to qualifications and opposing views, accumulating evidence suggests that both financial intermediaries and markets matter for growth and that reverse causality alone is not driving this relationship. Above, we have already discussed the identification problem and how the literature addressed this issue through the use of instrumental variables, panel techniques, documenting the mechanisms through which finance affects growth by using micro data, and finally through in-depth analysis of individual country cases and the impact of specific financial sector reforms.

Besides issues of identification, another problem that plagues the literature on finance and development has been the difficulty of in measuring financial development, which we have already mentioned. Banking problems provide a good example of how measurement issues can complicate the analysis. For example, when banking systems grow too quickly, booms are inevitably followed by busts, in which case size and depth may actually reflect policy distortions rather than development. Hence, it is not surprising that the econometric link between banking depth and aggregate economic growth has weakened in recent years, in particular when the data set includes the 1997-98 East Asia crisis (Rousseau and Wachtel, 2005) or is limited to turbulent Latin 
American countries (Loayza and Ranciere, 2005). Designing empirical proxies that capture more closely what is meant by financial development is an important area of further research. For example, recently there have been efforts to define and measure the access dimension of financial development, which is widely stressed in theory but mostly overlooked in empirical applications due to lack of availability of data (World Bank, 2007).

There are also issues related to nonlinearities and threshold effects. For example, below a certain level of development, small differences in financial development do not seem to help growth (Rioja and Valev, 2004a,b). Distinguishing between short-run and long-run effects of financial development is also important. Loayza and Ranciere (2005) estimate both effects using a pooled mean group estimator. Although they confirm a positive long-run effect, they also identify a negative short-run effect, where short-term surges in bank lending can actually signal the onset of financial crisis as discussed above. Also, financial development may boost income and allow developing countries catch up, but not lead to an increase in the long-run growth rate. Aghion, Howitt, and Mayer-Foulkes (2005) develop a model that predicts that low-income countries with low financial development will continue to fall behind the rest, whereas those reaching the higher level of financial development will converge. Their empirical results confirm that financial development helps an economy converge faster, but that there is no effect on steady-state growth.

Another challenge to the finance and growth literature comes in the form of individual country outliers. For example, China is often mentioned as a counterexample to the findings in finance and growth literature (Allen, Qian, and Qian 2005a,b). Despite weaknesses in its formal banking system, China is one of the fastest-growing economies in the world. Informal systems might substitute for formal systems. Indeed, in China, interprovincial differences in growth rates are highly correlated with banking debt, but negatively (BoyreauDebray, 2003; Boyreau-Debray and Wei, 2005). This emphasizes the importance of focusing on allocation of credit to the private sector, as opposed to all bank intermediation. Hence, mobilizing and pouring funds into the declining parts of the Chinese state enterprise system, as the main Chinese banks have been doing, has not been growth promoting. However, focusing on small and medium firms - which account for the most dynamic part of the Chinese economyshows that those firms receiving bank credit in recent years did tend to grow more quickly compared to those receiving funds from informal sources (Ayyagari, Demirgüç-Kunt, and Maksimovic, 2007). This suggests that the ability of informal mechanisms to substitute for formal financial systems might be exaggerated.

In summary, despite the weaknesses and qualifications, the accumulation of evidence suggests that financial development is crucial for growth. Although the evidence may not convince all skeptics, it is strong enough to motivate the policy 
makers to prioritize financial sector policies and devote attention to policy determinants of financial development as a mechanism for promoting growth.

\section{Determinants of Financial Development}

In the first part of the paper we showed that the bulk of the empirical literature on finance and development suggests that well-developed financial systems play an independent and causal role in promoting long-run economic growth. If finance is important for development, why do some countries have growthpromoting financial systems while others do not? And what can governments do to develop their financial systems?

\section{Historical Determinants}

Given the important role finance plays in promoting development, there is a growing body of research that examines determinants of financial development. One area of this line of research focuses on historical determinants of financial development and studies the legal, political, cultural, ethnic, and geographic differences across countries that may shape development of financial institutions and markets.

La Porta et al. (1997 and 1998) stress that differences in legal traditions shape the laws and enforcement mechanisms that protect the rights of outside investors, thus influencing financial development. Focusing on the differences between the two most influential legal traditions, the British Common Law and the French Civil Law, this view holds that legal traditions differ in terms of the priority they attach to protecting the rights of private investors against the state. Beck, Demirgüç-Kunt, and Levine (2003b and 2005), Beck and Levine (2005), and Levine (2005) also show that legal system adaptability is crucial and more flexible legal systems do a better job at meeting the continuously changing financial needs of the economy and promoting financial development.

Haber (2004), Pagano and Volpin (2001), and Rajan and Zingales (2003) focus on how forces of political economy shape national policies toward financial development and influence and change the political power of entrenched incumbents. According to this view, closed political systems are more likely to impede the development of financial systems that promote competition and threaten entrenched powers than open political systems. This is because centralized and powerful states are more responsive to and efficient at implementing policies that protect the interests of the elite than decentralized and competitive political systems with an assortment of checks and balances.

Stulz and Williamson (2003) emphasize the role of religion and culture in influencing development of institutions. Many scholars argue that religion shapes national views regarding institutions, including financial institutions. For example, it is said that the Catholic Church fosters "vertical bonds of authority" 
rather than "horizontal bonds of fellowship." This view suggests that Catholic and Muslim countries tend to develop cultures that maintain control, limiting competition and private property rights. Alesina et al. (2003) and Easterly and Levine $(1997,2003)$ focus on ethnic differences, instead. They argue that in highly ethnically diverse economies, the group that comes to power tends to implement policies that expropriate resources, restrict the rights of other groups, and prevent the growth of industries or sectors that threaten the ruling group.

Others stress the role of initial geographic endowments in determining attitudes towards development of different institutions (Engerman and Sokoloff, 1997; Acemoglu, Johnson, and Robinson, 2001). Acemoglu, Johnson, and Robinson (2001) focus on the disease environment and argue that the degree to which Europeans could settle in a land influenced the choice of colonization strategy with long-lasting implications on institutions. Engerman and Sokoloff (1997) focus on the geographic endowments and study the differential development of institutions in North America. They argue that the geographic conditions in the North that favored production of wheat and maize fostered a large middle class with egalitarian institutions, whereas the conditions in the South that led to the production of rice and sugarcane also led to the rise of a powerful elite and more closed institutions.

Beck, Demirgüç-Kunt, and Levine (2003a) investigate the relative importance of these historical determinants of financial development and find that differences in initial endowments and legal origins are robustly associated with development of financial institutions and markets. Thus, countries with common law origins with better protection of outside investors were more likely to develop financial institutions. But colonization strategy also mattered: Tropical environments, inhospitable to European settlement, were more likely to foster extractive institutions as opposed to institutions that promote financial development. ${ }^{6}$

Perhaps most important from a policy viewpoint, however, is the government's role in building efficient and inclusive financial systems. Hence, in the next section, we turn to the evidence on the role of regulations and economic policies in influencing financial development.

\section{Role of Policies}

Besides historical forces, government policies shape the structure and functioning of financial systems. Specifically, the degree of political and macroeconomic stability and the operation of legal, regulatory, and information systems all influence the financial contracting environment. Furthermore, governments influence the ownership of financial institutions as well as the degree of contestability by foreign and domestic sources, which affect the functioning of financial systems and the degree to which individuals have access

\footnotetext{
${ }^{6}$ Ayyagari, Demirgüç-Kunt, and Maksimovic (2006a,b) instead focus on property rights protection
} and show that legal origin is not a robust determinant whereas ethnic fractionalization is.

Finance, Financial Sector Policies, and Long-Run Growth 
to financial services. We now discuss each of these areas of government influence in greater detail.

\section{Political and Macroeconomic Environment}

Political turmoil may lead to macroeconomic instability and deterioration in business conditions. Civil strife and war destroys capital and infrastructure, and expropriations may follow military takeovers. Corruption and crime thrive in such environments, increasing cost of doing business and creating uncertainty about property rights. Detragiache, Gupta, and Tressel (2005) show that for lowincome countries political instability and corruption have a detrimental effect on financial development. Investigating the business environment for 80 countries using firm level survey data, Ayyagari, Demirgüç-Kunt, and Maksimovic (2005) find that political instability and crime are important obstacles to firm growth, particularly in African and Transition countries. Further, Beck, Demirgüç-Kunt, and Maksimovic (2004a) show that the negative impact of corruption on firm growth is most pronounced for smaller firms.

Given a stable political system, well-functioning financial systems also require fiscal discipline and stable macroeconomic policies on the part of governments. Monetary and fiscal policies affect the taxation of financial intermediaries and provision of financial services (Bencivenga and Smith, 1992; Huybens and Smith, 1999; Roubini and Sala-i-Martin, 1992, 1995). Often large financing requirements of governments crowd out private investment by increasing the required returns on government securities and absorbing the bulk of the savings mobilized by the financial system. Bank profitability does not necessarily suffer given the high yields on these securities, but the ability of the financial system to allocate resources efficiently is severely curtailed. Empirical studies have also shown that countries with lower and more stable inflation rates experience higher levels of banking and stock market development (Boyd, Levine, and Smith, 2001) and high inflation and real interest rates are associated with higher probability of systemic banking crises (Demirgüç-Kunt and Detragiache, 1998, 2005).

\section{Legal and Information Infrastructure}

Financial systems also require developed legal and information infrastructures to function well. Firms' ability to raise external finance in the formal financial system is quite limited if the rights of outside investors are not protected. Outside investors are reluctant to invest in companies if they will not be able to exert corporate governance and protect their investment from controlling shareholders/owners or the management of the companies. Thus, protection of property rights and effective enforcement of contracts are critical elements in financial system development.

Empirical evidence shows firms are able to access external finance in countries where legal enforcement is stronger (La Porta et al., 1997; Demirgüç- 
Kunt and Maksimovic, 1998; Beck, Demirgüç-Kunt, and Maksimovic, 2005), and that better creditor protection increases credit to the private sector (Djankov, McLiesh, and Shleifer, 2007). More effective legal systems allow more flexible and adaptable conflict resolution, increasing firms' access to finance (Djankov et al., 2007; Beck, Demirgüç-Kunt, and Levine, 2005). In countries where legal systems are more effective, financial systems have lower interest rate spreads and are more efficient (Demirgüç-Kunt, Laeven, and Levine, 2004; Laeven and Majnoni, 2005).

Timely availability of good-quality information is equally important, since this helps reduce information asymmetries between borrowers and lenders. The collection, processing, and use of borrowing history and other information relevant to household and small business lending - credit registries - have been rapidly growing in both the public and private sectors (see Miller, 2003 for an overview). Computer technology has also greatly improved the amount of information that can be analyzed to assess creditworthiness, such as through credit scoring techniques. Governments can play an important role in this process, and while establishment of public credit registries may discourage private entry, in several cases it has actually encouraged private registries to enter in order to provide a wider and deeper range of services. Governments are also important in creating and supporting the legal system needed for conflict resolution and contract enforcement, and strengthening accounting infrastructures to enable financial development.

Empirical results show that the volume of bank credit is significantly higher in countries with more information sharing (Jappelli and Pagano, 2002; Djankov, McLeish, and Shleifer, 2007). Firms also report lower financing obstacles with better credit information (Love and Mylenko, 2004). Detragiache, Gupta, and Tressel (2005) find that better access to information and speedier enforcement of contracts are associated with deeper financial systems even in low-income countries. Indeed, compared to high-income countries, in lower-income countries it is credit information more than legal enforcement that matters (Djankov, McLeish, and Shleifer, 2007).

\section{Regulation and Supervision}

For as long as there have been banks, there have also been governments regulating them. Although most economists agree that there is a role for government in the regulation and supervision of financial systems, the extent of this involvement is an issue of active debate (Barth, Caprio, and Levine; 2004, $2006,2008 a, b)$. One extreme view is the laissez-faire or invisible-hand approach, where there is no role for government in the financial system, and markets are expected to monitor and discipline financial institutions. This approach has been criticized for ignoring market failures because depositors, particularly small 
depositors, often find it too costly to be effective monitors. ${ }^{7}$ Thus, governments often act as delegated monitors for depositors, exploiting economies of scale to overcome costly information problems.

On the other hand, many advocate a more interventionist approach, where government regulation is seen as the solution to market failures (Stigler, 1971). According to this view, powerful supervisors are expected to ensure stability of the financial system and guide banks in their business decisions through regulation and supervision. This view relies on two crucial assumptions: first, that governments know better than markets, and second, that they act in the best interests of the society. To the extent that officials generally have limited knowledge and expertise in making business decisions and can be subject to political and regulatory capture, these assumptions will not be valid (Becker and Stigler, 1974; Haber, Maurer, and Razo, 2003).

Between the two extremes lies the private empowerment view of financial regulation. This view simultaneously recognizes the potential importance of market failures, which motivate government intervention, and political/regulatory failures, which suggest that supervisory agencies do not necessarily have incentives to ease market failures. The focus is on enabling markets, where there is an important role for governments in enhancing the ability and incentives of private agents to overcome information and transaction costs, so that private investors can exert effective governance over banks. Consequently, the private empowerment view seeks to provide supervisors with the responsibility and authority to induce banks to disclose accurate information to the public, so that private agents can more effectively monitor banks (Barth, Caprio, and Levine, 2006).

Empirical evidence overwhelmingly supports the private empowerment view. Although there is little evidence that empowering regulators enhances bank stability, there is evidence that regulations and supervisory practices that force accurate information disclosure and promote private sector monitoring boost the overall level of banking sector and stock market development (Barth, Caprio, and Levine, 2006).

Beck, Demirgüç-Kunt, and Levine (2006) show that bank supervisory practices that force accurate information disclosure ease external financing constraints of firms, whereas countries that empower their official supervisors actually make external financing constraints more severe by increasing the degree of corruption in bank lending. Consistent with these findings, DemirgüçKunt, Detragiache, and Tressel (2006) investigate compliance with Basel Core Principles of regulation and supervision and show that only information disclosure rules have a significant, positive impact on bank soundness. Finally,

\footnotetext{
7 Small depositors have to be protected, but banks also need to be protected against runs by uninformed depositors that may precipitate forced liquidations. Further, market imperfections may also prevent optimal resource allocation, as powerful banks may extract rents from firms, reducing their incentives to undertake profitable investments. See Levine (2005) for further discussion.
} 
Detragiache, Gupta, and Tressel (2005) find little significant impact of regulatory and supervisory practices on financial development of low-income countries, but note that where supervisory powers matter, greater supervisory powers reduce financial development. Furthermore, La Porta, Lopez-de-Silanes, and Shleifer, (2006) find a similarly positive effect of private monitoring and disciplining for stock market development. Laws and liability rules that mandate disclosure and facilitate private enforcement promote stock market development, while there is little evidence for a positive effect of public enforcement.

Related to the debate on different approaches for regulation and supervision, is the important debate on whether prudential regulation and safety nets designed for developed countries can be successfully transplanted to developing countries. Research shows that financial sector policy that is considered appropriate in advanced economies can prove ineffective or even counterproductive in weak institutional environments of developing countries. For example, powerful regulators are not significantly associated with increased corruption in banking in countries with strong institutions that provide checks and balances, but lead to greater capture and corruption in lower-income countries. However, although empowering the markets and focusing on information disclosure are policies that promote bank stability most effectively in countries where there is strong rule of law, we do not observe negative effects of such policies even in low-income countries (Beck, Demirgüç-Kunt, and Levine, 2006). Consistent with these results, Demirgüç-Kunt, Detragiache, and Tressel (2006) show that compliance with the information disclosure rules of Basel Core Principles promotes bank stability where there is a strong rule of law. For developing countries, these results have important implications for which aspects of the Basel II accord (which was designed for and by regulators in advanced economies) to adopt and over what time period. In particular, the complicated rules and procedures for determining bank capital adequacy presuppose expertise and governance conditions that simply do not exist in most low-income countries.

Similarly, research has questioned safety net design, particularly adoption of deposit insurance in developing countries, by highlighting the potential costs of explicit schemes-lower market discipline, higher financial fragility, and lower financial development-in countries where complementary institutions are not strong enough to keep these costs under control (Demirgüç-Kunt and Kane, 2002; Demirgüç-Kunt and Detragiache, 2002; Demirgüç-Kunt and Huizinga, 2004; Cull, Senbet, and Sorge, 2005). These findings are particularly important for lower-income countries with underdeveloped institutions. For example, Detragiache, Gupta, and Tressel (2005) also find that presence of an explicit deposit insurance system does not lead to more deposit mobilization in lowincome countries; to the contrary it is associated with lower levels of deposits. Using a sample of developed and developing countries, Cecchetti and Krause (2004) also find that explicit deposit insurance results in less credit provision to 
the private sector. Demirgüç-Kunt, Kane, and Laeven (2008) summarize the cross-country evidence on the impact of deposit insurance and assess the policy complications that emerge in developing countries by reviewing individualcountry experiences with deposit insurance-including issues raised by the EU's Deposit Insurance directive, banking reform in Russia, and policy efforts to protect depositors in China.

\section{Contestability and Efficiency}

Policy makers around the world frequently express concern about whether their countries' bank competition policies are appropriately designed to produce wellfunctioning and stable banks. Globalization and the resulting consolidation in banking have further spurred interest in this issue, leading to an active public policy debate. Competition policies in banking may involve difficult tradeoffs. Although greater competition may enhance the efficiency of banks with positive implications for economic growth, greater competition may also destabilize banks with costly repercussions for the economy.

Recent research has shown that contrary to conventional wisdom, the tradeoffs are exaggerated when it comes to bank competition. Greater competition - as captured by lower entry barriers, fewer regulatory restrictions on bank activities, greater banking freedom, and better overall institutional development-is good for efficiency, good for stability, and good for firms' access to finance (Berger et al., 2004). Also see Beck, Demirgüç-Kunt, and Maksimovic (2004b), Beck, Demirgüç-Kunt, and Levine (2006b), Claessens and Laeven (2004), and Demirgüç-Kunt, Laeven, and Levine (2004). Indeed, regulations that interfere with competition make banks less efficient, more fragile, and reduce firms' access to finance. Thus, it seems to be a good idea for governments to encourage competition in banking by reducing the unnecessary impediments to entry and activity restrictions. Similarly, improving the institutional environment and allowing greater freedoms in banking and economy in general would lead to desirable outcomes.

Ownership is another important dimension of competition in banking. As we discuss further in the two following subsections, research shows that while foreign banking is associated with generally positive outcomes, state ownership is associated with higher margins, greater fragility, and even less and lower quality of access. These results highlight the importance of removing impediments to foreign entry and provide further justification for bank privatization policies. Finally, bank concentration, which has been the focus of much policy discussion, seems not to be a good proxy for the overall competitive environment per se as its impact often depends on the existing regulatory and institutional framework. Hence governments would do better to focus on improving the underlying regulatory and institutional environment (as discussed in the subsections above, "Legal and Information Infrastructure" and 
"Regulation and Supervision") and ownership structure to promote contestable financial systems, rather than trying to reduce concentration levels in banking.

\section{Government Ownership of Financial Institutions}

A growing body of evidence shows that government ownership of banks everywhere, but especially in developing countries, leads to lower levels of financial development, more concentrated lending, and lower economic growth, and greater systemic fragility (La Porta, Lopez-de-Silanes, and Shleifer, 2002; Barth, Caprio, and Levine, 2004). Furthermore, there is no evidence that stateowned banks help the poor; rather, state-owned banks tend to funnel credit to politically favored and commercially unviable projects (Sapienza, 2004; Cole, 2005; Dinc, 2005; Khwaja and Mian, 2005; Beck, Demirgüç-Kunt, and Levine, 2006a). Even in the area of access to financial services, recent evidence suggests that bank customers face higher barriers to credit services in banking systems that are predominantly government-owned (Beck, Demirgüç-Kunt, and Martinez Peria, 2007). Although in some cases, government financial institutions have entered into public-private partnership to overcome coordination failures and first-mover disincentives (De la Torre, Gozzi, and Schmukler, 2007), it is unclear whether these initiatives would have been undertaken by the private sector if state-owned institutions did not play such a dominant role in the economy. Overall, a large body of empirical evidence suggests that governments do not have a comparative advantage in owning financial institutions.

Nevertheless, privatization also entails risks and needs careful design (Megginson and Netter, 2008). Studies of privatization processes suggest the preferred strategy is moving slowly but deliberately with bank privatization, while preparing state banks for sale and addressing weaknesses in the overall incentive environment. On average, bank privatization tends to improve performance over continued state ownership. There are advantages to full rather than partial privatizations; and in weak institutional environments, selling to a strategic investor and inviting foreign interests to participate in the process increase the benefits (see Clarke, Cull, and Shirley, 2005 for an overview). Privatization, however, is not a panacea, and privatizing banks without addressing weaknesses in the underlying incentive environment and market structure will not lead to a deeper and more efficient financial system.

\section{Financial Liberalization}

Many countries liberalized their financial systems in the 1980s and 1990s with mixed results. Liberalization, including deregulation of interest rates and more relaxed entry policies, often led to significant financial development, particularly in countries where there was significant repression, but the enthusiasm with which financial liberalization was adopted in some countries in the absence of or slow implementation of institutional development also left many financial systems vulnerable to systemic crises (Demirgüç-Kunt and Detragiache, 1999). 
Poor sequencing of financial liberalization in a poorly prepared contractual and supervisory environment contributed to bank insolvencies as banks protected by implicit and explicit government guarantees aggressively took advantage of new opportunities to increase risk, without the necessary lending skills. Banking crises in Argentina, Chile, Mexico, and Turkey in the 1980s and 1990s have been attributed to these factors (Demirgüç-Kunt and Detragiache, 2005). Although many sub-Saharan African countries did not suffer instability following liberalization, they did suffer sharp declines in financial intermediation due to the absence of an effective contractual and informational framework (see Honohan and Beck, 2007). These experiences with financial liberalization underline the importance of sequencing liberalization with policy, regulatory, and institutional improvements.

The relationship between the exchange rate regime and financial liberalization is another area of active debate. One of the reasons this is an important issue is because the choice of exchange rate regime may influence the extent to which the impact of external shocks affect financial stability. For instance, flexible exchange rates may have a stabilizing effect on the financial system since the exchange rate can absorb some of the real shocks to the economy (Mundell, 1961). Flexible regimes may also curtail the tendency of countries to overborrow in foreign currency and discourage banks from funding dangerous lending booms through external credit (Eichengreen and Hausmann, 1999). Further, with a fixed exchange rate (and even more so with a currency board), lender of last resort operations are severely limited, since domestic monetary expansion risks undermining confidence in the currency peg.

On the other hand, a commitment to a currency peg may reduce the probability of banking crises by disciplining policy makers (Eichengreen and Rose, 1998). The lack of an effective lender of last resort may also discourage risktaking by bankers, decreasing the likelihood of a banking crisis. Finally, developing countries are often plagued by lack of credibility and limited access to international markets, and suffer from more pronounced effects of exchange rate volatility due to their high liability dollarization. Thus, the additional transparency and credibility associated with fixed exchange rates may insulate a country from contagion (Calvo, 1999).

Empirically, Arteta and Eichengreen (2000) find that countries with fixed and flexible exchange rates are equally susceptible to banking crises. In contrast, Domac and Martinez Peria (2003) find that adopting a fixed exchange rate regime (i) diminishes the likelihood of a banking crisis in developing countries and (ii) increases the economic cost of a crisis if one occurs.

Studies on the impact of dollarization on financial fragility similarly reveal mixed evidence. Dollarization is a symptom of weak domestic currencies and volatile real exchange rates and thus may be associated with fragility. Arteta (2003) investigates the impact of deposit and credit dollarization for a large number of developing and transition countries and finds no evidence that 
dollarization increases fragility. De Nicolo, Honohan, and Ize (2003) perform a similar test but measure fragility using average $Z$-scores (measuring the distance to default for the banking system, which is different from the actual occurrence of a systemic crisis) and nonperforming loans across a large number of countries. In contrast to Arteta's results, they find that dollarization is positively related to both measures of bank fragility. More research is needed in these areas to guide the ongoing policy discussion on the impact of exchange rate policies.

With financial liberalization, developing economies are increasingly liberalizing restrictions on the entry of foreign financial institutions. Although governments have worried about whether allowing foreign banks to take a large ownership share in the banking system could damage financial and economic performance, the bulk of the empirical research in this area, particularly drawing on the experience of Latin American and Eastern European countries, suggests that facilitating entry of reputable foreign institutions to the local market should be welcomed. Arrival or expansion of foreign banks can also be disruptive as the Indian experience shows evidence of cream-skimming by foreign banks (Gormley, 2004). Even there however, in the years following entry, foreign banks have started expanding their clientele base. Overall, a large body of evidence suggests that over time foreign bank entry brings competition, improves efficiency, lifts the quality of the financial infrastructure, and expands access (Claessens, Demirgüç-Kunt, and Huizinga, 2001; Clarke, Cull, and Martinez Peria, 2001). ${ }^{8}$

However, as the African experience illustrates, foreign bank entry cannot guarantee rapid financial development in the absence of sound contractual and informational weaknesses (Honohan and Beck, 2007). Such weaknesses can prevent low-income countries from reaping full benefits of opening their markets to foreign providers of financial services, and can potentially explain the finding that greater foreign bank penetration is associated with lower levels of financial development (Detragiache, Tressel, and Gupta, 2005). ${ }^{9}$ However, addressing these weaknesses is likely to allow foreign banks to act as an important catalyst for the sort of financial development that promotes growth.

\footnotetext{
${ }^{8}$ Although in some countries like Pakistan, foreign banks have been shown to lend less to smaller, more opaque borrowers because they rely on hard information (Mian, 2006), evidence from Eastern Europe has shown that foreign banks eventually go down market and increase small business lending (De Haas and Naaborg, 2005). This is consistent with recent research that shows as new transaction-based lending techniques have been developed, where large foreign institutions have greater advantage, relationship lending, thus small, domestic institutions have become less important for SME lending (Berger and Udell, 2006).

9 Another explanation why cross-country correlations between foreign bank penetration and financial development may be negative in low-income countries is that in most of those countries, foreign bank entry was through privatization of failed government banks.
} 
Although many support liberalizing financial systems, there are also concerns that this leaves them more open to volatility and crises. ${ }^{10}$ As discussed above, one way of containing such volatility is stronger fundamentals, hence proper sequencing of reforms. ${ }^{11}$ Policy discussion has also focused on proper design of capital controls, which could prevent or mitigate the effects of sudden shifts in foreign capital. Controls can take the form of restrictions on outflows; restrictions on aggregate inflows; restrictions on short-term flows (a la Chile); or a Tobin tax, aimed at imposing a small uniform tax on all foreign exchange transactions, regardless of their nature. There is a large literature on the effects of capital controls, but overall, these empirical studies suggest that these controls work at best temporarily, with the effects diminishing over time, and are not effective in preventing spillovers from very large shocks (Kaminsky and Schmukler, 2001).

Besides debt and equity flows, workers' remittances, funds received from migrants working abroad, have grown steadily in recent years becoming the second largest source of external finance after foreign direct investment. Furthermore, unlike other capital flows, remittances tend to be stable even during periods of economic downturns and crises. Recent research also suggests that remittances do promote financial development (Aggarwal, Demirgüç-Kunt and Martinez Peria, 2006). Other studies emphasize the importance of financial development in allowing countries to make the most out of capital flows. For example, Hermes and Lensink (2003) show that a more developed financial system positively contributes to the process of technological diffusion associated with foreign direct investment.

\section{Facilitating Access}

Access to financial services has increasingly been receiving greater emphasis over the recent years (World Bank, 2007). One reason is that modern development theory sees the lack of access to finance as a critical mechanism for generating persistent income inequality, as well as slower growth. Another is the observation that small enterprises and poor households face much greater obstacles in their ability to access finance all around the world, but particularly in developing countries.

\footnotetext{
${ }^{10}$ Opening up allows firms to raise resources from abroad, but Levine and Schmukler $(2006,2007)$ show that it reduces the trading activity of these firms on domestic stock exchanges, negatively affecting the liquidity of other firms that do not internationalize, while Gozzi, Levine, and Schmukler (2008) show that internationalization has large distributional effects, helping big firms relative to small ones. Ferreira and Matos (2005) show that with increased cross-listing, foreign ownership of shares traded on the local exchanges also increases.

11 Note that studies suggest volatility tends to decrease in the long run, with more integrated markets having lower volatility due to better diversification and development of the financial sector (Bekaert and Harvey, 2003). However, liberalization does also increase the probability of crisis (Demirgüç-Kunt and Detragiache, 1999).
} 
What does access to finance mean? Broad access to financial services implies an absence of price and nonprice barriers. It is difficult to define and measure because there are many dimensions of access, including availability, cost, and range and quality of services being offered. Although there is much data on financial sector development more broadly, until recently there was very little data on usage and access to finance, both for households and firms. Hence, there is also very limited analysis on the impact of access to finance on economic development. Research using firm-level survey data suggests that financing obstacles are the most constraining among different barriers to growth (Ayyagari, Demirgüç-Kunt, and Maksimovic, 2005). Financing obstacles are also found to be highest and most constraining for the growth of smaller firms (Beck, Demirgüç-Kunt, and Maksimovic, 2004a). At the household level, lack of access to credit is shown to perpetuate poverty because poor households reduce their children's education (Jacoby, 1994; Jacoby and Skoufias, 1997). Similarly, Dehejia and Gatti (2005) find that child labor rates are higher in countries with underdeveloped financial systems, while Beegle, Dehejia, and Gatti (2007) show that transitory income shocks lead to greater increases in child labor in countries with poorly functioning financial systems. A better understanding of what the chief obstacles to improving access are, and access to which type of financial services has the greater impact on reducing poverty and promoting growth, will need to wait for availability of better data and analysis in this area.

There are many different reasons why the poor do not have access to finance-loans, savings accounts, insurance services. Social and physical distance from the formal financial system may matter. The poor may not have anybody in their social network who knows the various services that are available to them. Lack of education may make it difficult for them to overcome problems with filling out loan applications, and the small number of transactions they are likely to undertake may make the loan officers think it is not worthwhile to help them. As financial institutions are likely to be in richer neighborhoods, physical distance may also matter; banks simply may not be near the poor (Beck and De la Torre, 2006). Specifically for access to credit services, there are two important problems. First, the poor have no collateral, and cannot borrow against their future income because they tend not to have steady jobs or income streams to keep track of. Second, dealing with small transactions is costly for the financial institutions. Ceilings on the rates financial institutions can charge backfire and limit access to the poor even more.

Microfinance-specialized institutions that serve the poor-tries to overcome these problems in innovative ways. Loan officers come from similar social status as the borrowers and go to the poor instead of waiting for the poor to come to them. Microcredit also involves education as much as it provides credit. Group lending schemes not only improve repayment incentives and monitoring through peer pressure, but they are also a way of building support networks and educating borrowers. 
Has microfinance fulfilled its promise? Microfinance allows poor people to have more direct access, but development of microfinance around the world has been very non-uniform, with significant penetration rates only in a few countries like Bangladesh, Indonesia, and Thailand (Honohan, 2004). Group lending is very costly since labor cost per dollar of transactions needs to be high by design. The most controversial aspect of microfinance, however, has been the extent of subsidy required to provide this access. Overall, the microfinance sector remains heavily grant and subsidy dependent. Skeptics question whether microfinance is the best way to provide those subsidies and point out that development of mainstream finance is a more promising way to reach the poor and alleviate poverty in significant ways (World Bank, 2007; Cull, Demirgüç-Kunt, and Morduch, 2008).

There are also good political economy reasons why we should not focus on the poor and ask how we can make microfinance more viable, but instead ask how financial services can be made available for all (Rajan, 2006). ${ }^{12}$ The poor lack the political clout to demand better services, and subsidies may spoil the credit culture. By defining the issue more broadly to include the middle class who often also lack access, would make it more likely that promotion of financial assess will be made a priority.

What can governments do to promote access? Many of the policies recommended above to enhance the overall development of the financial sector will also help increase access. However, the overlap is not perfect, and explicit prioritization of access is therefore important. For example, certain regulations aimed at financial stability or combating terrorism can restrict access of small firms and poor households. Or focusing on development of offshore financial centers to export wholesale financial services may lead to the neglect of onshore financial infrastructures necessary for access of small firms and individuals. Also, it is important to set realistic goals; not all potential borrowers are creditworthy, and many banking crises were precipitated by overly relaxed credit policies.

First and foremost, governments can further access by making and encouraging infrastructure improvements. However, prioritizing different reform efforts is important and recent research also suggests that in low-income countries improving information infrastructures seems to yield more immediate access benefits than legal reforms (Djankov, McLeish, and Shleifer, 2007). But legal reforms are also important, and among those there is evidence that while protection of property rights against the state is more important for financial development generally, other aspects of contract enforcement (such as institutions relating to collateral) may be more important for access (Haselmann, Pistor, and Vig, 2006).

${ }^{12}$ Rajan (2006) argues, "let's not kill the microfinance movement with kindness. If we want it to become more than a fad ... it has to follow the clear and unsentimental path of adding value and making money. On that path lies the possibility of a true and large-scale escape from poverty." 
Institutional reform is a long-term process and specific policy actions can help boost access sooner. There are a wide range of such measures, ranging from specific legislation to underpin nonblank intermediation including leasing and factoring; technologies based on the Internet and mobile phones; development of credit registries; protection against money laundering and terrorist finance without jeopardizing household access; and others.

For example, at the household level, giving each individual a national identification number and creating credit registries where lenders share information about their clients' repayment records would help since all borrowers could then borrow using their future access to credit as collateral (Rajan, 2006). Reducing costs of registering and repossessing collateral is also crucial. In Brazil for example, inability to repossess property has contributed to the cost of the housing finance program, keeping the mortgage rates too high to be affordable for the poor. Governments can also be instrumental in facilitating innovative technologies to improve access. For example in Mexico, a program developed by Nafin, a government development bank, allows many small suppliers to use their receivables from large credit-worthy buyers to receive working capital financing (Klapper, 2006). This type of trade finance is called reverse factoring and effectively allows small firms to borrow based on the creditworthiness of their buyers, allowing them to borrow more at cheaper rates. ${ }^{13}$

Government regulation can also help. Removal of interest ceilings, or usury laws, would allow institutions to charge the rates that they need to be profitable and improve access. These regulations end up hurting the very poor they are trying to protect as the supply of these services completely dry up. Antipredatory lending and truth-in-lending requirements are also very important since households may also be forced into overborrowing by unscrupulous lenders. Antidiscrimination policies may also help against cases of active or passive discrimination against the poor or different ethnic groups.

It is also important to ensure that other complex regulations-such as Basel II regulations that are intended to help banks minimize costly bank failures - do not inadvertently penalize small borrowers and hurt access by failing to make full allowance for the potential for a portfolio of SME loans to achieve risk pooling. Financial regulations can also prevent the emergence of institutions better suited to the needs of lower-income households or smaller firms. Rigid chartering rules, high capital adequacy requirements, and very strict accounting requirements may reduce the ability of institutions to serve the poorer segments of the society. As many households are interested in savings services but not in credit services, considering and regulating savings mobilization separately from

\footnotetext{
${ }^{13}$ Also see Berger and Udell (2006) for a discussion of different innovative technologies that can expand access of small firms even in the absence of a strong institutional environment. De la Torre, Gozzi, and Schmukler (2005) include other such public-private partnership examples of expanding access.
} 
credit services may be helpful (Claessens, 2005). For example in South Africa, extension of bank regulation and supervision to microfinance institutions reduced their capacity to offer their services profitably.

Governments can also opt to stimulate access more directly. Examples include the U.S. Treasury's Electronic Transfer Accounts (ETAs) to increase use of bank accounts; the U.S. Community Reinvestment Act (CRA) to improve access to credit services; and legal measures adopted by the United Kingdom, France, Sweden, and Ireland, among others. However, there is little consensus on the success of those schemes (Peachey and Roe, 2006; Claessens, 2005) and whether they can be replicated in developing countries. The experiences with credit extensions, especially to improve the maturity structure of debt and reach the SMEs, are extensive in both developed and developing countries. However, both the rationale for and effectiveness of those interventions are much more doubtful (see Caprio and Demirgüç-Kunt, 1998; Beck and Demirgüç-Kunt, 2006). As already discussed above, interventions through ownership of government institutions have also not been successful, overall.

Last but perhaps most important, governments can improve access by increasing competition in the financial sector. Beck, Levine, and Levkov (2008) find that policies in the United States that increase bank competition and bank efficiency disproportionately help the poor and reduce income inequality. Beck, Demirgüç-Kunt, and Levine (2007) similarly find that better-developed financial systems reduce income inequality by helping the poor in a cross-country study. Indeed, Levine, Levkov, and Rubinstein (2008) show that greater competition in banking that intensifies economy-wide competition tends to reduce the effects of racial discrimination, disproportionately helping disadvantaged groups. The impact of competition in the financial sector may work to improve resource allocation through many mechanisms. As financial institutions find their traditional business coming under competition, they seek out new lines of profitable opportunities, including lending to the SMEs and the poor. Given the right incentives, private sector can develop and make use of new technologieslike credit scoring - to reach the underserved segments. As already discussed above, foreign banks' role in improving the competition environment and improving access is important. There is accumulating evidence that over time, foreign banks can enhance access. Indeed, multinational banks have been leading the way in expanding access all around the world.

Finally, should all countries follow these recommendations? Although the general messages will not be dissimilar, the directions in which the financial sector needs improvement in different countries will be based on their initial conditions (World Bank, 2001 and 2007). Furthermore, good policy making draws inputs from many sources, and research is only one such input. Implementation of policy requires complementing the results of research analysis with practitioner experience, hence tempering and tailoring this advice to individual country circumstances. In general, these reforms are likely to be 
most challenging for low-income countries, where the legacy of financial repression and state ownership has generally hampered the development of a vigorous private financial system, where the underlying legal and information infrastructure is weak, and where achieving minimum efficient scale will be difficult.

\section{Conclusion}

Although the different methodologies used to study the finance-growth connection have distinct strengths and weaknesses, they produce remarkably consistent results. The main, tentative conclusions that we garner from recent empirical work are as follows:

- Countries with a better-developed financial system tend to grow faster. Specifically, both financial intermediaries and markets matter for growth. The size of the banking system and the liquidity of stock markets are each positively linked with economic growth.

- Simultaneity bias does not seem to be the cause of this result.

- Better-functioning financial systems ease the external financing constraints that impede firm and industrial expansion. Thus, one channel through which financial development matters for growth is by easing the ability of constrained industries and firms to access external capital and expand.

We state these conclusions simply, but stress that we hold them with a significant degree of skepticism. These findings may certainly be refuted, qualified, and clarified by future work and we have listed various avenues for future research in the text. Nevertheless, our assessment of a large-albeit not unanimous-body of evidence supports these three conclusions.

To the extent that financial systems exert a first-order influence on economic growth, this motivates research into the determinants of well-functioning financial systems. A new and exciting literature researches this question. Some work focuses on the direct laws and regulations shaping the operation of financial systems, while complementary work examines the broader political, historical, and institutional determinants of financial development.

Subject to even greater qualifications, some lessons can also be drawn about policy foundations of financial development.

- Well-functioning financial systems need stable macroeconomic policies and strong legal and information systems. Making infrastructure improvements a priority is a must.

- Promoting a contestable financial sector - as characterized by lower entry barriers, fewer regulatory restrictions on bank activities, and greater banking freedoms-is essential for improving depth, efficiency, and 
access. This means reducing government ownership through careful privatization, and domestic and international liberalization including foreign entry. Opening up is also accompanied by risks, however, particularly a higher risk of financial crisis, and therefore needs to be synchronized with improvements in institutional improvements.

- Governments have an important role to play as regulators. But empirical evidence suggests the best approach to regulation is one which empowers the markets, rather than creating all-powerful regulators who may be subject to corruption and political and industry capture. Empowering the market entails enforcing accurate and timely information disclosure and providing the right incentives for market participants to make sure they remain vigilant monitors - for example, through avoiding generous and mispriced deposit insurance, or forbearance policies that distort risktaking incentives. Research also questions the wisdom of transplanting developed-country practice to developing countries. Often regulations considered appropriate in developed economies prove ineffective or counterproductive in weaker institutional settings: Explicit deposit insurance may destabilize the very financial system it is meant to protect, and powerful supervisors may be more prone to corruption and extracting rents. Hence, the importance of institutional factors that need strengthening to support these policies.

- Governments also have an important role to play in facilitating broad access to financial services - that is, in expanding the availability of the range of financial services to a broader set of households, firms, and sectors in the economy. Government policies should focus on building good institutions and encouraging competition-including foreign entry-and good prudential regulation to provide the private sector with appropriate incentive structures and broaden access. Governments can facilitate the development of an enabling financial infrastructure and encourage adoption of new technologies, but attempts at direct intervention, for example through subsidies or ownership of financial institutions, are more likely than not to be counterproductive.

Finally, although the general messages will be similar, the priorities and the extent to which the financial sector needs improvement in each country will depend on initial conditions, with the reforms being the most challenging for low-income countries. Good policy making complements research with practitioner experience and tailors advice to individual country circumstances. 


\section{References}

Acemoglu, D., S. Johnson, and J.A. Robinson. 2001. "The Colonial Origins of Comparative Development: An Empirical Investigation." American Economic Review 91: 1369-1401.

Aggarwal, R., A. Demirgüç-Kunt, and M. Martinez Peria. 2006. “Do Remittances Promote Financial Development?" Evidence from a Panel of Developing Countries." Unpublished. World Bank, Washington, D.C.

Aghion, P., P. Howitt, and D. Mayer-Foulkes. 2005. “The Effect of Financial Development on Convergence: Theory and Evidence." Quarterly Journal of Economics 120(1): 173-222.

Alesina, A., A. Devleeschauwer, W. Easterly, S. Kurlat, and R. Wacziarg. 2003. "Fractionalization." Journal of Economic Growth 8(2).

Allen, F., J. Qian, and M. Qian. 2005a. "Law, Finance, and Economic Growth in China." Journal of Financial Economics 77(1): 57-116.

—_ 2005b. "China's Financial System: Past, Present, and Future." Wharton School Financial Institutions Center Working Paper.

Arellano, M. and O. Bover. 1995. "Another Look at the Instrumental-Variable Estimation of Error-Components Models." Journal of Econometrics 68: 29-52.

Arellano, M., and S. Bond. 1991. "Some Tests of Specification for Panel Data: Monte Carlo Evidence and an Application to Employment Equations." Review of Economic Studies 58: 277-97.

Arestis, P., P.O. Demetriades, and K.B. Luintel. 2001. "Financial Development and Economic Growth: The Role of Stock Markets." Journal of Money, Credit, and Banking 33: 16-41.

Arteta, C. 2003. “Are Financially Dollarized Countries More Prone to Costly Crises?" International Finance Discussion Paper, Board of the Governors of the Federal Reserve System, No. 763.

Arteta, C., and B. Eichengreen. 2000. "Banking Crises in Emerging Markets: Presumptions and Evidence." In M. Blejer and M. Skreb, eds., Financial Policies in Emerging Markets. Cambridge, MA: MIT Press.

Atje, R., and B. Jovanovic. 1993. "Stock Markets and Development." European Economic Review 37: 632-40.

Ayyagari, M., A. Demirgüç-Kunt, and M. Maksimovic. 2005. "How Important Are Financing Constraints? The Role of Finance in the Business Environment." Unpublished. World Bank, Washington, D.C.

—_ 2006a. "How Well Do Institutional Theories Explain Firms' Perceptions of Property Rights?" Review of Financial Studies, forthcoming. 
- 2006b. "What Determines Protection of Property Rights? An Analysis of Direct and Indirect Effects." Unpublished. World Bank, Washington, D.C.

—. 2007. "Formal versus Informal Finance: Evidence from China." Unpublished. World Bank, Washington, D.C.

Bagehot, W. 1873. Lombard Street: A Description of the Money Market. Homewood, IL: Richard D. Irwin (1962 Edition).

Barth, J.R., G. Caprio, and R. Levine. 2004. "Bank Regulation and Supervision: What Works Best?" Journal of Financial Intermediation 13: 205-48.

—_. 2006. Rethinking Bank Regulation-'Till Angels Govern. Cambridge University Press.

__ 2008a. "Reassessing the Rationale and Practice of Bank Regulation and Supervision After Basel II." Current Development in Monetary and Financial Law 5: 41-67.

—_. 2008b. "Bank Regulations are Changing: For Better or Worse?" Comparative Economics Studies, forthcoming.

Beck, T., and A. de la Torre. 2006. "The Basic Analytics of Access to Financial Services." Unpublished. World Bank, Washington, D.C.

Beck, T., and A. Demirgüç-Kunt. 2006. "Small and Medium-Sized Enterprises: Access to Finance as Growth Constraint." Journal of Banking and Finance, forthcoming.

Beck, T., A. Demirgüç-Kunt, L. Laeven, and R. Levine. 2008. “Finance, Firm Size, and Growth." Journal of Money, Credit, and Banking, forthcoming.

Beck, T., A. Demirgüç-Kunt, and R. Levine. 2007. “Finance, Inequality and the Poor." Journal of Economic Growth 12: 27-49.

- 2006a. "Bank Supervision and Corruption in Lending." Journal of Monetary Economics 53: 2131-63.

- 2006b. "Bank Concentration, Competition, and Crises: First Results." Journal of Banking and Finance 30: 1581-1603.

- 2005. "Law and Firms' Access to Finance." American Law and Economics Review 7: 211-52.

- 2003a. "Law, Endowments, and Finance." Journal of Financial Economics 70: 137-81.

- 2003b. "Law and Finance: Why Does Legal Origin Matter?" Journal of Comparative Economics 31: 653-75.

Beck, T., A. Demirgüç-Kunt, R. Levine, and V. Maksimovic. 2001. “Financial Structure and Economic Development: Firm, Industry, and Country Evidence." In Financial Structure and Economic Growth: A Cross-Country 
Comparison of Banks, Markets, and Development, A. Demirgüç-Kunt and R. Levine, eds. Cambridge, MA: MIT Press: 189-242.

Beck, T., A. Demirgüç-Kunt, and A. Maksimovic. 2004a. "Financial and Legal Constraints to Firm Growth: Does Size Matter?" Journal of Finance 60" 13777.

- 2004b. "Bank Competition and Access to Finance: International Evidence." Journal of Money, Credit, and Banking 36(3): 627-48.

Beck, T., A. Demirgüç-Kunt, and M. Soledad Martinez Peria. 2007. "Banking Services for Everyone? Barriers to Bank Access and Use around the World." Policy Research Working Paper 4079. World Bank, Washington, DC.

Beck, T., and R. Levine. 2002. "Industry Growth and Capital Allocation: Does Having a Market- or Bank-Based System Matter?" Journal of Financial Economics 64: 147-80.

- 2004. "Stock Markets, Banks and Growth: Panel Evidence." Journal of Banking and Finance 28: 423-42.

- 2005. "Legal Institutions and Financial Development." In Handbook of Institutional Economics, Claude Menard and Mary Shirley, eds. Norwell MA: Kluwer Academic Publishers.

Beck, T., R. Levine, and A. Levkov. 2008. “Big Bad Banks: The Impact of U.S. Branch Deregulation on Income Distribution." Brown University, Unpublished.

- 2000. "Finance and the Sources of Growth." Journal of Financial Economics 58: 261-300.

Becker, G., and G. Stigler. 1974. "Law Enforcement, Malfeasance, and the Compensation of Enforcers." Journal of Legal Studies 3: 1-18.

Beegle, K., R. Dehejia, and R. Gatti. 2007. "Child Labor and Agricultural Shocks.” Journal of Development Economics, forthcoming.

Bekaert, G., and C.R. Harvey. 2003. “Emerging Markets Finance.” Journal of Empirical Finance 10: 3-56.

Bekaert, G., C.R. Harvey, and C. Lundblad. 2005. “Does Financial Liberalization Spur Growth?" Journal of Financial Economics 77: 57-116.

—. 2001. "Emerging Equity Markets and Economic Development." Journal of Development Economics 66: 465-504.

Bencivenga, V.R., and B.D. Smith. 1993. "Some Consequences of Credit Rationing in an Endogenous Growth Model." Journal of Economic Dynamics and Control 17: 97-122. 
- 1992. "Deficits, Inflation and the Banking System in Developing Countries: The Optimal Degree of Financial Repression." Oxford Economic Papers 44: 767-90.

—_ . "Financial Intermediation and Endogenous Growth." Review of Economics Studies 58: 195-209.

Bencivenga, V.R., B.D. Smith, and R.M. Starr. 1995. “Transactions Costs, Technological Choice, and Endogenous Growth." Journal of Economic Theory 67: 53-177.

Berger, A., and G.F. Udell. 2006. "A More Complete Conceptual Framework for Financing of Small and Medium Enterprises." Journal of Banking and Finance 23.

Berger, A., A. Demirgüç-Kunt, J. Haubrich, and R. Levine. 2004. "Introduction: Bank Concentration and Competition: An Evolution in the Making." Journal of Money, Credit, and Banking 36(3): 433-53.

Bertrand, M., A.S. Schoar, and D. Thesmar. 2004. "Banking Deregulation and Industry Structure: Evidence from the French Banking Reforms of 1985." Discussion Paper No. 4488. Centre for Economic Policy Research.

Bhide, A. 1993. "The Hidden Costs of Stock Market Liquidity." Journal of Financial Economics 34: 1-51.

Blackburn, K., and V.T.Y. Hung. 1998. "A Theory of Growth, Financial Development, and Trade." Economica 65: 107-24.

Boyd, J.H., and B.D. Smith. 1992. "Intermediation and the Equilibrium Allocation of Investment Capital: Implications for Economic Development." Journal of Monetary Economics 30: 409-32.

Boyd, J.H., and E.C. Prescott. 1986. “Financial Intermediary-Coalitions.” Journal of Economics Theory 38: 211-32.

Boyd, J.H., R. Levine, and B.D. Smith. 2001. "The Impact of Inflation on Financial Sector Performance." Journal of Monetary Economics 47: 221-48.

Boyreau-Debray, G. 2003. "Financial Intermediation and Growth-Chinese Style." Policy Research Working Paper 3027. World Bank, Washington, D.C.

Boyreau-Debray, G, and W. Shang-Jin. 2005. "Pitfalls of a State-Dominated Financial System: The Case of China." Working Paper 11214. National Bureau of Economic Research.

Calvo, G. 1999. “Testimony on Full Dollarization.” Paper presented before a joint hearing of the subcommittees on Economic Policy and International Trade and Finance, U.S. Congress, April. 
Caprio, G., L. Laeven, and R. Levine. 2007. “Governance and Bank Valuation.” Journal of Financial Intermediation 16: 584-617.

Caprio, G., and A. Demirgüç-Kunt. 1998. “Term Finance: Theory and Evidence.” World Bank Research Observer 13:2, August.

Carosso, V. 1970. Investment Banking in America. Cambridge, MA: Harvard University Press.

Cecchetti, S., and S. Krause. 2004. "Deposit Insurance and External Finance." Working Paper No. 10908. National Bureau of Economic Research.

Claessens, S. 2005. "Access to Financial Services: A Review of the Issues and Public Policy Objectives." Policy Research Working Paper 3589. World Bank, Washington, D.C.

Claessens, S., and L. Laeven. 2004. "What Drives Bank Competition? Some International Evidence." Journal of Money, Credit, and Banking 36(3): 563-83.

Claessens, S., A. Demirgüç-Kunt, and H. Huizinga. 2001. "How Does Foreign Entry Affect Domestic Banking Markets?" Journal of Banking and Finance 25(5): 891-911.

Clarke, G., R. Cull, and M. Martinez Peria. 2001. “Does Foreign Bank Penetration Reduce Access to Credit in Developing Countries: Evidence from Asking Borrowers." Policy Research Working Paper 2716. World Bank, Washington, D.C.

Clarke, G., R. Cull, and M. Shirley. 2005. "Bank Privatization in Developing Countries: A Summary of Lessons and Findings." Journal of Banking and Finance 29: 1905-30.

Clarke, G., R. Cull, M. Martinez Peria, and S. Sanchez. 2003. “Foreign Bank Entry: Experience, Implications for Developing Countries and Agenda for Further Research." World Bank Research Observer 18: 25-59.

Cole, S. 2005. "Fixing Market Failures or Fixing Elections? Elections, Banks, and Agricultural Lending in India." Harvard Business School. Unpublished.

Cull, R., A. Demirgüç-Kunt, and J. Morduch. 2008. "Microfinance: The Next Capitalist Revolution?" Journal of Economic Perspectives, forthcoming.

Cull, R., L. Senbet, and M. Sorge. 2005. “Deposit Insurance and Financial Development." Journal of Money, Credit, and Banking 37: 43-82.

De Haas, R., and I. Naaborg. 2005. “Does Foreign Bank Entry Reduce Small Firms' Access to Credit: Evidence from European Transition Economies." Working Paper 50. Dutch National Bank.

Dehejia, R.H., and R. Gatti. 2005. "Child Labor: The Role of Financial Development and Income Variability across Countries." Economic Development and Cultural Change 53(4): 913-32. 
De la Fuente, A. and J.M. Marin. 1996. "Innovation, Bank Monitoring, and Endogenous Financial Development." Journal of Monetary Economics 38: 269-301.

De la Torre, A., J.C. Gozzi, and S. Schmukler. 2007. "Innovative Experiences in Access to Finance: Market Friendly Roles for the Visible Hand?" Stanford University Press and the World Bank, forthcoming.

Demirgüç-Kunt, A., and E. Detragiache. 2005. "Cross-Country Empirical Studies of Systemic Bank Distress: A Survey." In P. Davis, ed., Financial Instability, Asset Prices, and Credit. National Institute Economic Review, forthcoming.

___ 2002. "Does Deposit Insurance Increase Banking System Stability? An Empirical Investigation." Journal of Monetary Economics 49(7): 1373-406.

__ 1999. "Financial Liberalization and Financial Fragility." In B. Pleskovic and J. Stiglitz, eds., Proceedings of the Annual World Bank Conference on Development Economics. Washington, D.C.: The World Bank, pp. 332-34.

Demirgüç-Kunt, A., E. Detragiache, and T. Tressel. 2006. "Banking on the Principles: Compliance with Basel Core Principles and Bank Soundness." Unpublished. World Bank, Washington, D.C.

Demirgüç-Kunt, A., and H. Huizinga. 2004. "Market Discipline and Deposit Insurance." Journal of Monetary Economics 51: 375-99.

Demirgüç-Kunt, A., and E. Kane. 2002. “Deposit Insurance around the Globe: Where Does It Work?" Journal of Economic Perspectives 16(2): 175-96.

Demirgüç-Kunt, A., and R. Levine. 2001. Financial Structure and Economic Growth: A Cross-Country Comparison of Banks, Markets, and Development. Cambridge, MA: MIT Press.

Demirgüç-Kunt, A., E. Kane, and L. Laeven. 2008. Deposit Insurance around the World: Issues of Design and Implementation. Cambridge, MA: MIT Press, forthcoming.

Demirgüç-Kunt, A., L. Laeven, and R. Levine. 2004. "Regulations, Market Structure, Institutions, and the Cost of Financial Intermediation." Journal of Money, Credit, and Banking 36(3): 593-622.

Demirgüç-Kunt, A., and V. Maksimovic. 1998. "Law, Finance, and Firm Growth." Journal of Finance 53: 2107-37.

De Nicolo, G., P. Honohan, and A. Ize. 2003. "Dollarization of the Banking System: Good or Bad." Working Paper 03/146. International Monetary Fund.

Detragiache, E., P. Gupta, and T. Tressel. 2005. "Finance in Lower-Income Countries: An Empirical Exploration.” Working Paper 05/167. International Monetary Fund. 
Dinc, S. 2005. "Politicians and Banks. Political Influences on Government-Owned Banks in Emerging Countries." Journal of Financial Economics 77: 453-79.

Djankov, S., C. McLeish, and A. Shleifer. 2007. "Private Credit in 129 Countries." Journal of Financial Economics, forthcoming.

Domac, I., and M. Martinez Peria. 2003. "Banking Crises and Exchange Rate Regimes: Is There a Link?" Journal of International Economics 61(1): 41-72.

Easterly, W., and R. Levine. 1997. "Africa's Growth Tragedy: Policies and Ethnic Divisions." Quarterly Journal of Economics 112: 1203-50.

—_. 2003. "Tropics, Germs, and Crops: How Endowments Influence Economic Development." Journal of Monetary Economics 50: 3-39.

Eichengreen, B., and A. Rose. 1998. "Staying Afloat when the Wind Shifts: External Factors and Emerging-Market Banking Crises." Working Paper No. 6370, January. National Bureau of Economic Research.

Eichengreen, B., and R. Hausmann. 1999. "Exchange Rates and Financial Fragility." Working Paper No. 7418. National Bureau of Economic Research.

Engerman, S.L., and K.L. Sokoloff. 1997. “Factor Endowments, Institutions, and Differential Paths of Growth among New World Economies: A View from Economic Historians of the United States." In S. Haber, ed., How Latin America Fell Behind. Stanford, CA: Stanford University Press, pp. 260-304.

Ferreira, M., and P. Matos. 2005. "The Colors of Investors' Money: Which Firms Attract Institutional Investors from around the World?" ISCTE Business School-Lisbon.

Galetovic, A. 1996. "Specialization, Intermediation and Growth." Journal of Monetary Economics 38: 549-59.

Galor, O., and J. Zeira. 1993. "Income Distribution and Macroeconomics." Review of Economic Studies 60: 35-52.

Goldsmith, R.W. 1969. Financial Structure and Development. New Haven, CT: Yale University Press.

Gormley, T.A. 2004. "Banking Competition in Developing Countries: Does Foreign Bank Entry Improve Credit Access?" http://ssrn.com/ abstract $=879244$.

Gozzi, J.C., R. Levine, and S. Schmukler. 2008. "Internationalization and the Evolution of Corporate Valuations." Journal of Financial Economics, forthcoming.

Greenwood, J., and B. Jovanovic. 1990. "Financial Development, Growth, and the Distribution of Income." Journal of Political Economy 98: 1076-1107. 
Greenwood, J., and B. Smith. 1996. "Financial Markets in Development, and the Development of Financial Markets." Journal of Economic Dynamics and Control 21: 145-81.

Grossman, S.J., and O. Hart. 1980. "Takeover Bids, the Free-Rider Problem, and the Theory of the Corporation." Bell Journal of Economics 11: 42-64.

Grossman, S.J., and J. Stiglitz. 1980. “On the Impossibility of Informationally Efficient Markets." American Economic Review 70: 393-408.

Guiso, L., P. Sapienza, and L. Zingales. 2002. “Does Local Financial Development Matter?" Working Paper No. 8922. National Bureau of Economic Research.

Gurley, J.G., and E.S. Shaw. 1955. “Financial Aspects of Economic Development.” American Economic Review 45: 515-38.

Haber, S.H. 1997. "Financial Markets and Industrial Development: A Comparative Study of Governmental Regulation, Financial Innovation and Industrial Structure in Brazil and Mexico, 1840-1940." In S. Haber, ed., How Latin America Fell Behind? Stanford, CA: Stanford University Press, pp. 146178.

- 2004. "Political Competition and Economic Growth: Lessons from the Political Economy of Bank Regulation in the United States and Mexico". Stanford University. Unpublished.

Haber, S.H., N. Maurer, and A. Razo. 2003. The Politics of Property Rights: Political Instability, Credible Commitments, and Economic Growth in Mexico. Cambridge University Press.

Hansen, L. P. 1982. "Large Sample Properties of Generalized Methods of Moments Estimator." Econometrica 50(4): 1029-54.

Harrison, P., O. Sussman, and J. Zeira. 1999. "Finance and Growth: Theory and Evidence." Federal Reserve Board (Division of Research and Statistics), Washington, D.C. Unpublished.

Haselmann, R.F.H., K. Pistor, and V. Vig. 2006. "How Law Affects Lending." Columbia Law and Economics Working Paper No. 285. Columbia University.

Hermes, N., and R. Lensink. 2003. "Foreign Direct Investment, Financial Development and Economic Growth." Journal of Development Studies 38.

Hicks, J. 1969. A Theory of Economic History. Oxford: Clarendon Press.

Higgins, R.C. 1977. "How Much Growth Can a Firm Afford?" Financial Management 6: 3-16.

Holmstrom, B., and J. Tirole. 1993. "Market Liquidity and Performance Monitoring." Journal of Political Economy 101: 678-709. 
Honohan, P. 2004. "Financial Development, Growth, and Poverty: How Close Are the Links?" In C. Goodhart, ed., Financial Development and Economic Growth: Explaining the Links. London: Palgrave.

Honohan, P., and T. Beck. 2007. Making Finance Work for Africa. Washington, D.C.: World Bank.

Huybens, E., and R. Smith. 1999. "Inflation, Financial Markets, and Long-Run Real Activity." Journal of Monetary Economics 43: 283-315.

Jacoby, H.G. 1994. “Borrowing Constraints and Progress Through School: Evidence from Peru." Review of Economics and Statistics 76: 151-60.

Jacoby, H.G., and S. Emmanuel. 1997. “Risk, Financial Markets, and Human Capital in a Developing Country." The Review of Economic Studies 64(3, July): 311-35.

Jappelli, T., and M. Pagano. 2002. "Information Sharing, Lending and Defaults: Cross-Country Evidence." Journal of Banking and Finance 26(10): 2017-45.

Jayaratne, J., and P.E. Strahan. 1996. "The Finance-Growth Nexus: Evidence from Bank Branch Deregulation." Quarterly Journal of Economics 111: 639-70.

Jensen, M., and W.R. Meckling. 1976. "Theory of the Firm, Managerial Behavior, Agency Costs and Ownership Structure." Journal of Financial Economics 3: 305-60.

Jones, C. 1998. Introduction to Economic Growth. New York: Norton.

Kaminsky, G., and S. Schmukler. 2001. “On Financial Booms and Crashes: Regional Patterns, Time Patterns, and Financial Liberalization." Policy Research Paper. World Bank, Washington, D.C.

Khwaja, A.I., and A. Mian. 2005. “Do Lenders Favor Politically Connected Firms? Rent Provision in an Emerging Financial Market." Quarterly Journal of Economics 120.

King, R.G., and R. Levine. 1993a. "Finance and Growth: Schumpeter Might Be Right." Quarterly Journal of Economics 108: 717-38.

— 1993b. "Finance, Entrepreneurship, and Growth: Theory and Evidence." Journal of Monetary Economics 32: 513-42.

—. 1993c. "Financial Intermediation and Economic Development." In Financial Intermediation in the Construction of Europe, C. Mayer and X. Vives, eds. London: Centre for Economic Policy Research, pp. 156-89.

King, R.G., and C.I. Plosser. 1986. "Money as the Mechanism of Exchange." Journal of Monetary Economics 17: 93-115.

Klapper, L. 2006. “The Role of Factoring for Financing Small and Medium Enterprises." Journal of Banking and Finance, forthcoming. 
Kyle, A.S. 1984. "Market Structure, Information, Futures Markets, and Price Formation." In International Agricultural Trade: Advanced Readings in Price Formation, Market Structure, and Price Instability, G.G. Storey, A. Schmitz, and A.H. Sarris, eds. Boulder, CO: Westview.

Laeven, L., and R. Levine. 2008. "Complex Ownership Structures and Corporate Valuations " Review of Financial Studies, forthcoming.

Laeven, L., and G. Majnoni. 2005. “Does Judicial Efficiency Lower the Cost of Credit?" Journal of Banking and Finance 29: 1791-812.

Lamoreaux, N. 1994. Insider Lending: Banks, Personal Connections, and Economic Development in Industrial New England, New York: Cambridge University Press.

La Porta, R., F. Lopez-de-Silanes, and A. Shleifer. 2006. "What Works in Securities Laws?" Journal of Finance, forthcoming.

__ 2002. "Government Ownership of Commercial Banks." Journal of Finance 57: $265-301$.

La Porta, R., F. Lopez-de-Silanes, A. Shleifer, and R. Vishny. 1999. "Corporate Ownership Around the World." Journal of Finance 54: 471-517.

___ 1998. "Law and Finance." Journal of Political Economy 106: 1113-55.

. 1997. "Legal Determinants of External Finance." Journal of Finance 52: 1131-50.

Levine, R. 2002. "Bank-Based or Market-Based Financial Systems: Which is Better?" Journal of Financial Intermediation 11: 398-428.

—_ 1998. "The Legal Environment, Banks, and Long-Run Economic Growth." Journal of Money, Credit, and Banking 30: 596-613.

—_. 1999. "Law, Finance, and Economic Growth." Journal of Financial Intermediation 8: 36-67.

—_ 1991. "Stock Markets, Growth, and Tax Policy." Journal of Finance 46: 1445-65.

—_ 2005. "Law, Endowments, and Property Rights." Journal of Economic Perspectives 19: 61-88.

Levine, R., A. Levkov, and Y. Rubinstein. 2008. "Competition and Race Discrimination." Brown University. Unpublished.

Levine, R., and D. Renelt. 1992. "A Sensitivity Analysis of Cross-Country Growth Regressions." American Economic Review 82: 942-63.

Levine, R. and S. Schmukler. 2007. "Migration, Spillovers, and Trade Diversion: The Impact of Internationalization on Stock Market Liquidity." Journal of Banking and Finance 31: 1595-1612. 
- 2006. "Internationalization and Stock Market Liquidity." Review of Finance 10: 153-187.

Levine, R., and S. Zervos. 1998. "Stock Markets, Banks, and Economic Growth." American Economic Review 88: 537-58.

Levine, R., N. Loayza, and T. Beck. 2000. "Financial Intermediation and Growth: Causality and Causes." Journal of Monetary Economics 46: 31-77.

Loayza, N., and R. Ranciere. 2005. “Financial Development, Financial Fragility, and Growth." Working Paper No. 05/170. International Monetary Fund.

Love, I., and N. Mylenko. 2004. "Credit Reporting and Financing Constraints." Policy Research Working Paper 3142. World Bank, Washington, D.C.

Lucas, R.E. 1988. “On the Mechanics of Economic Development." Journal of Monetary Economics 22: 3-42.

McKinnon, R.I. 1973. Money and Capital in Economic Development. Washington, D.C.: Brookings Institution.

Megginson, W.L., and J.M. Netter. 2008. "From State to Market: A Survey of Empirical Studies on Privatization." Journal of Economic Literature, forthcoming.

Meier, G.M., and D. Seers. 1984. Pioneers in Development. New York: Oxford University Press.

Merton, R.C. 1987. “A Simple Model of Capital Market Equilibrium with Incomplete Information." Journal of Finance 42: 483-510.

Mian, Atif. 2006. “Distance Constraints: The Limits of Foreign Lending in Poor Economies." Journal of Finance 61(3): 1465-1505.

Miller, M. 2003. Credit Reporting Systems and the International Economy. Cambridge, MA: MIT Press.

Miller, M.H. 1998. "Financial Markets and Economic Growth." Journal of Applied Corporate Finance 11: 8-14.

Morales, M.F. 2003. "Financial Intermediation in a Model of Growth Through Creative Descruction." Macroeconomic Dynamics 7: 363-93.

Mundell, R. 1961. "A Theory of Optimum Currency Areas." American Economic Review 51: 717-25.

Pagano, M., and P. Volpin. 2001. “The Political Economy of Finance." Oxford Review of Economic Policy 17: 502-19.

Patrick, H. 1966. "Financial Development and Economic Growth in Underdeveloped Countries." Economic Development Cultural Change 14: 174189. 
Peachey, S., and A. Roe. 2006. "Access to Finance, Measuring the Contribution of Savings Banks." World Savings Banks Institute.

Rajan, R. 2006. “Separate and Unequal." Finance and Development (March), International Monetary Fund, Washington D.C., 56-57.

Rajan, R.G., and L. Zingales. 2003. Saving Capitalism from the Capitalists. New York: Random House.

__ 1998. "Financial Dependence and Growth." American Economic Review 88: 559-86.

Rioja, F., and N. Valev. 2004a. "Does One Size Fit All? A Reexamination of the Finance and Growth Relationship." Journal of Development Economics 74(2): 429-47.

- 2004b. "Finance and the Sources of Growth at Various Stages of Economic Development." Economic Inquiry 42(1): 127-40.

Roubini, N., and Sala-i-Martin, X. 1992. "Financial Repression and Economic Growth." Journal of Development Economics 39: 5-30.

- 1995. "A Growth Model of Inflation, Tax Evasion, and Financial Repression." Journal of Monetary Economics 35: 275-301.

Rousseau, P., and P. Wachtel. 2005. "Economic Growth and Financial Depth: Is the Relationship Extinct Already?" Working Paper 05-15. Stern School of Business.

—_ 2000. "Equity Markets and Growth: Cross-Country Evidence on Timing and Outcomes, 1980-1995." Journal of Business and Finance 24: 1933-57.

Sapienza, P. 2004. “The Effects of Government Ownership on Bank Lending." Journal of Financial Economics 72: 357-84.

Schumpeter, J.A. 1912/1934. Theorie der wirtschaftlichen Entwicklung. Leipzig: Duncker \& Humblot. English translation published in 1934 as The Theory of Economic Development. Cambridge, MA: Harvard University Press.

Sirri, E.R., and P. Tufano. 1995. "The Economics of Pooling." In The Global Financial System: A Functional Approach, D.B. Crane, et al., eds. Boston, MA: Harvard Business School Press, pp. 81-128.

Smith, A. 1776. An Inquiry into the Nature and Causes of the Wealth of Nations. London: W. Stahan \& T. Cadell.

Stigler, G. 1971. “The Theory of Economic Regulation.” Bell Journal of Economics and Management Science 2: 3-21.

Stulz, R.M., and R. Williamson. 2003. "Culture, Openness, and Finance.” Journal of Financial Economics 70: 313-49. 
Sussman, O. 1993. "A Theory of Financial Development." In Finance and Development: Issues and Experience, A. Giovannini, ed. Cambridge: Cambridge University Press, 29-64.

Weil, David. 2005. Economic Growth. New York: Pearson, Addison-Wesley.

Williamson, S.D., and R. Wright. 1994. "Barter and Monetary Exchange under Private Information." American Economic Review 84: 104-23.

World Bank. 2007. “Access to Finance: Measurement, Impact and Policy.” Policy Research Report. Washington, D.C.

_ _ 2001. "Finance for Growth: Policy Choices in a Volatile World." Policy Research Report. Washington, D.C. 


\section{Eco-Audit}

\section{Environmental Benefits Statement}

The Commission on Growth and Development is committed to preserving endangered forests and natural resources. The World Bank's Office of the Publisher has chosen to print these Working Papers on 100 percent postconsumer recycled paper, processed chlorine free, in accordance with the recommended standards for paper usage set by Green Press Initiative-a nonprofit program supporting publishers in using fiber that is not sourced from endangered forests. For more information, visit www.greenpressinitiative.org.

The printing of all the Working Papers in this Series on recycled paper saved the following:

\begin{tabular}{|c|c|c|c|c|}
\hline Trees $^{*}$ & Solid Waste & Water & Net Greenhouse Gases & Total Energy \\
\hline 48 & 2,247 & 17,500 & 4,216 & 33 mil. \\
\hline $\begin{array}{c}{ }^{*} 40 \text { inches in } \\
\text { height and 6-8 } \\
\text { inches in diameter }\end{array}$ & Pounds & Gallons & Pounds CO2 Equivalent & BTUs \\
\hline
\end{tabular}

\section{green




\section{The Commission on Growth and Development Working Paper Series}

2. Exchange Rate Economics, by John Williamson, March 2008

3. Normalizing Industrial Policy, by Dani Rodrik, March 2008

4. The Real Exchange Rate and Economic Growth, by Barry Eichengreen, March 2008

5. Globalization, Growth and Distribution: Framing the Questions, by Ravi Kanbur, March 2008

6. Growth Strategies and Dynamics: Insights from Country Experiences, by Mohamed A. El-Erian and Michael Spence, March 2008

7. Political Competition, Policy Making, and the Quality of Public Policies in Costa Rica, by Fabrice Lehoucq, April 2008

8. Leadership for Growth, Development, and Poverty Reduction: An African Viewpoint and Experience, by Benjamin William Mkapa, April 2008

9. Growth Strategies for Africa, by Paul Collier, April 2008

10. The Role of Institutions in Growth and Development, by Daron Acemoglu and James Robinson, April 2008

11. Finance, Financial Sector Policies, and Long-Run Growth, by Asli Demirgüç-Kunt and Ross Levine, April 2008

\section{Forthcoming Papers in the Series:}

Cities: Engines of Growth and Prosperity for Developing Countries? by Gilles Duranton (April 2008)

Housing Policy in Developing Countries: The Importance of the Informal Economy, by Richard Arnott (April 2008) 
$I^{\prime}$ $\mathrm{n}$ this paper, we review research on (1) the relation between finance and growth and (2) the policy and institutional determinants of financial development. Governments play a central role in shaping the operation of financial systems and the degree to which large segments of the economy have access to financial services.

Asli Demirgüç-Kunt, Senior Research Manager, Finance and Private Sector, Development Research Group, World Bank

Ross Levine, James and Merryl Tisch Professor of Economics, and Director of the William R. Rhodes Center for International Economics, Brown University
Commission on Growth and Development Montek Ahluwalia Edmar Bacha Dr. Boediono Lord John Browne Kemal Derviş Alejandro Foxley Goh Chok Tong Han Duck-soo Danuta Hübner Carin Jämtin Pedro-Pablo Kuczynski Danny Leipziger, Vice Chair Trevor Manuel Mahmoud Mohieldin Ngozi N. Okonjo-Iweala Robert Rubin Robert Solow Michael Spence, Chair Sir K. Dwight Venner Ernesto Zedillo Zhou Xiaochuan

The mandate of the Commission on Growth and Development is to gather the best understanding there is about the policies and strategies that underlie rapid economic growth and poverty reduction.

The Commission's audience is the leaders of developing countries. The Commission is supported by the governments of Australia, Sweden, the Netherlands, and United Kingdom, The William and Flora Hewlett Foundation, and The World Bank Group. 